\title{
The Honey-Eating Birds and the Tree of Life: Notes on Rgveda 1.164.20-22
}

\author{
Per-Johan Norelius
}

Gothenburg

\begin{abstract}
The following article is an attempt at interpretation of the oftdiscussed "riddle" of the birds (Rgveda 1.164.20-22). Recognizing that the riddle, as much of Vedic poetry, operates on several "levels" (cosmic, ritual, etc.) and may be meant to be answered in more than one way, the present approach sees the enigma as drawing on mythical and cosmological imagery current in early Vedic times; imagery that also finds expressions elsewhere in the Rgveda and later texts. Following the majority of earlier interpreters, I take the fig-tree on which the birds are perched to be the world-tree, and the "figs" or "honey" on which they feed to be soma or amrta-. Following Hillebrandt and Kuiper, the two birds in 1.164.20 are interpreted as the sun and the moon. The image of one or more birds (suparná-) associated with the drink of immortality is traced through the Vedic literature; in some places it is possible to identify it as Soma (from late Rgvedic times equated to the moon). It is further suggested that both the bird and the world-tree are associated with the spring or receptacle of soma in heaven, which, following Witzel, is identified as the Seven
\end{abstract}


Seers, the constellation Ursa Maior. The article is concluded by a discussion of the Vedic imagery of a world-tree and a drink of immortality, and its parallels in Indo-European and Eurasian myths and cosmologies.

Keywords: riddles, Rgveda, Vedic religion, soma, cosmology, myth, axis mundi, tree of life, Indo-European.

\section{The riddle and its interpreters}

It is not my intention to provide yet another exegesis of the "riddlehymn" R.gveda $1.164 ;{ }^{1}$ while there are certainly many unsolved problems in this enigmatic text, the somewhat more modest purpose of the present paper is to shed some new light on the, probably, most oft-discussed stanzas of the hymn: 20-22, the famous "riddle" of the birds. difficulties:

Linguistically, the stanzas concerned present no great

Two birds, ${ }^{2}$ intimate companions, clasp the same tree;

One of them eats the sweet fig; ${ }^{3}$ the other watches without eating.

\footnotetext{
${ }^{1}$ Discussions of this particular hymn include Haug 1875 (still very readable); Deussen 1906, pp. 105-19 (who sees the hymn as an early example of Vedic "monism"); Kunhan Raja 1956 (an edition and translation of RV 1.164 with the commentaries of Sāyaṇa and Ātmānanda); Agrawala 1963 (a book-length translation-cum-study, often highly subjective and hazardous in its use of much younger materials); Oldenberg 1909-12: I, pp. 157-60; Renou 1967, pp. 88-93 (both dealing mainly with linguistic issues; the verses discussed here are not treated by Oldenberg); Brown 1968 (interpreting the various images used in the hymn in the light of early Vedic cosmology); Houben 2000 (suggesting a connection of many of the stanzas with the Pravargya rite). Somewhat lengthy discussions can also be found in translations such as Geldner, O'Flaherty, and Jamison \& Brereton. Among studies devoted specifically to the stanzas 20-22, mention should be made of Thieme 1949, pp. 55-73 (an original cosmological interpretation which we will have occasion to return to) and Johnson 1980, pp. 42-65 (elaborating on Geldner's interpretation of the two birds as a learned and an ignorant priest or poet, for which see below).

${ }^{2}$ We will return later on to the meaning of suparná-

${ }^{3}$ Thieme (1949, p. 63) rightly rejects earlier, imprecise renderings of pippala-, such as Geldner's "Beere"; "pippala heißt im gesamten indischen Altertum und auch heute noch ein ganz bestimmter Feigenbaum, die Ficus religiosa, und ihre Frucht". This is the tree mostly known as aśvattha- in Sanskrit literature.
} 
Where birds unblinkingly shriek ${ }^{4}$ for a share of the amrta- ${ }^{5}$ for the distributions ${ }^{6}-$

here, the mighty guardian of the whole world, the inspired one, ${ }^{7}$ has entered me, the ignorant.

In that very tree on which all the honey-eating birds settle down and breed,

at its top, they say, is the sweet fig. One who does not know the Father will not attain it. ${ }^{8}$

\footnotetext{
${ }^{4}$ abhi- svár- means (Böhtlingk \& Roth, s.v. svar) "mit Tönen begrüssen, singend einfallen, einstimmen".

5 In which sense the word is used here - as "immortality" or as the "food or drink of immortality", "ambrosia" (amŕta- being etymologically related to the Greek word) is (as often) difficult to determine. Much speaks, as we shall see, for the latter meaning.

${ }^{6}$ The semantic meaning of vidátha- is clear enough: it refers to a congregation, one of the chief functions of which is the distribution of wealth in the form of spoils or rewards. (Cf. Mayrhofer 1986, s.v.: "(festliche) Zuteilung".) This function is implied in the present verse by the word bhägá-, "share". The etymology of vidatha- is a more controversial matter. Thieme's (op. cit., pp. 35-49) derivation from vi- $d h \bar{a}$ - and Kuiper's $(1974,1979)$ from $v i-d \bar{a}$ - (connecting it with vi dayate), both meaning "to distribute", are attractive but suffer from linguistic difficulties; the accent is in the wrong place, and the unaspirated $-d$ - is problematic when it comes to Thieme's suggestion. Kuiper's (1979) attempt to save his etymology by postulating a protoVedic accentuation on the penultimate syllable in words ending with -atha-, demands too much special pleading. Another, phonetically more plausible, etymology, first proposed by Geldner and endorsed by Oldenberg (1967, pp. 108-11) and Houben (2000, p. 521 n. 113), derives the word from vid- "to know, to find"; the specialized knowledge or wisdom of the participants in the vidatha- would then have given this sort of congregation its name. As will be seen, wisdom or sacerdotal learning is a central theme in the stanzas under discussion. The motif of distribution should, however, not be downplayed, as in Houben's (loc. cit.) somewhat unprecise rendering "congregation", or in Johnon's picture of a "symposium contest" between learned poets (on which cf. Kuiper 1979, p. 273: “... only correct in so far as the distribution of wealth must have been part of a socio-religious contest and, being apparently a kind of potlach, was a contest in itself").

${ }^{7}$ On the meaning of dhî́ra- in the RV, cf. Gonda 1963, chap. V.

8 dvá suparnáa sayújā sákhāyā samānám vrkșám pári șasvajāte / táyor anyáh pippalam svādv átty ánaśnann anyó abhí cākaśīti //

yátrā suparnạ́ amritasya bhāgám ánimeșam vidáthābhisváranti / inó viśvasya bhúvanasya gopáh sá mā dhìraḥ pákam átrá̀ viveśa //

yásmin vrkșé madhvádah suparṇá niviśánte súvate cádhi viśve / tásyéd āhuḥ pippalam svādv ágre tán nón naśad yáh pitáram ná véda //
} 
Interpretations of the meaning of the two birds in st. 20 abound. Leaving aside the anachronistic native tradition which makes the figeating bird the embodied soul foolishly enjoying the ephemeral pleasures of the world, and the non-eating bird, God or the supreme soul, ${ }^{9}$ the birds have been interpreted variously as sun and moon, ${ }^{10}$ day and night, ${ }^{11}$ a learned and an ignorant priest (or a novice), ${ }^{12}$ the waxing and waning moon, ${ }^{13}$ the sun and the gharma pot used in the Pravargya rite. ${ }^{14}$ Of course, it is possible - even likely - that the hymn operates on several levels (cosmological, ritualistic, etc.), and that different meanings are implied in one and the same passage. While the present discussion will deal mainly with possible cosmological associations, it should be made clear that these do not necessarily exclude other interpretations; I do not think, for instance, that the view that makes the tree in the verses a metaphorical "tree of knowledge" (Geldner, Brown, Johnson ${ }^{15}$ ), whose fruits are eaten by learned or inspired priests ("birds"), is incompatible with the other main line of interpretation, which holds that it is the "world-tree" or the "tree of life" (Deussen, Thieme, Kuiper, Houben).

Indeed, it is hard to deny the connection of the tree and its fruits to knowledge or wisdom: ${ }^{16}$ only the one who "knows the Father" ${ }^{17}$ can reach the fruit at its top; and the poet's own confession of ignorance ("the inspired one has entered me, the ignorant") suggests a kinship

\footnotetext{
${ }^{9}$ Muṇuaka Upaniṣad 3.1.1; Śvetāśvatara Upanișad 4.6-7; Cūlikā Upaniṣad 8; Mbh 14.47.15 (critical edition). This interpretation is followed by medieval commentators such as Sāyana (on RV 1.164.20).

${ }^{10}$ Hillebrandt 1913, p. 104; Kuiper 1983, pp. 126-27. This possibility was first brought up, though ultimately rejected, by Haug (p. 483).

${ }^{11}$ Deussen 1906, pp. 112-13.

${ }_{12}^{12}$ Geldner ad loc.; Brown 1968, p. 208; Johnson, loc. cit.

${ }^{13}$ Thieme, loc. cit.

${ }^{14}$ Houben 2000, pp. 520-21.

${ }^{15}$ Cf. also Kunhan Raja ("the fruits of wisdom", 1956 p. xxxii). This author's opinion that "the tree can only be the universe" (p. 37) is perhaps inspired by the inverted tree as an image of the world in Bhagavadgitta $16.1 \mathrm{ff}$.

${ }^{16}$ It may be of importance that the birds are referred to as sákhāyā, "companions", as this term is elsewhere sometimes used to denote members of a learned congregation of poets or priests (cf. Elizarenkova 1997, p. 27, commenting on RV 10.71, a hymn that, like much of 1.164 , deals with the theme of vác- or sacred speech).

${ }^{17}$ There exist various suggestions as to the identity of this figure (Agni: Brown, p. 214; Heaven: Haug, p. 285; "der Allvater": Geldner; the sun: Houben, p. 522). If the "Father", as cautiously suggested here, is the fig-eating bird in st. 20, then Soma may be the answer (cf. below).
} 
with the birds that do not reach the fruit. This contrast between eating and non-eating has induced some writers (Geldner, Brown, Johnson ${ }^{18}$ ) to see a hierarchical relationship between the two birds in st. 20; the bird eating the fig being superior to the one that doesn't, as opposed to the view of native tradition. This is a tempting conclusion, though it is not certain that the one non-eating bird in st. 20 should be counted among the several birds desiring the "sweet fig" in st. $22 .{ }^{19}$ In fact, it seems odd that the author of the hymn would speak of only one eating bird in st. 20 if nothing distinguished it from the many birds in the next couple of verses. Any hierarchical relationship in the stanzas would rather, I think - and this view will be supported with comparisons to other passages - be between the one eating bird in st. 20 and the many birds in $21-22$. While the bird in st. 20 is already perched on the tree and eating the desirable figs, the other birds are described as anxiously shrieking for these figs, which are hard to obtain - being at the top of the tree, where they can be reached only by one who has the required knowledge. The birds are said to shriek "for a share of the amrta- (ambrosia), for the distributions", where the amrita-, of course, is identical with the "honey" or the "fig", and the "distributions" (vidátha-) refer to an apportioning of wealth. The birds, then, seek a "share" of that which the bird in st. 20 already is in possession of. It is possible that this bird is identical with the "Father", on whom the attainment of the figs depends. If so, this bird may be responsible for the apportioning of the figs among the other birds; indeed, there are some analogous passages which support this conclusion, as we shall see. ${ }^{20}$

Something should be said on the word suparná- (lit. the "fairfeathered one"), tentatively translated above as "bird". In classical Sanskrit, the word means "eagle", and it has usually been so translated also in the Veda. While it clearly denotes some kind of bird of prey

\footnotetext{
${ }^{18}$ Also Lommel 1978, p. 518.

${ }^{19}$ Cf. Thieme's (pp. 57-8) criticism of Geldner's view.

${ }^{20}$ If the designation "Father" is to be understood literally, the image may be one of a (male) parent bird feeding its young (bi-parental care being predominant among birds); the bird pecks the food, then feeds it to the young from its beak. Johnson (1980, pp. 51-2) thinks the two birds are a male and a female (grammatically possible in the case of $d v \bar{a}$ suparṇá sayújā sákhāyā, though the masculine anyáh ... anyó would seem to exclude such a conclusion) or a parent bird and its young, and that the one is feeding the other by regurgitating its food. The "watching" bird would be looking on as the other one swallows the figs, which it will then regurgitate.
} 
already in the $\mathrm{RV}$, it is however not certain that it has the meaning "eagle" here; nor can it be excluded that it may be used to designate a number of birds, rather than a single species. ${ }^{21}$ In the hymns 4.26 and 27 , relating the myth of the theft of the soma by a bird, the avian protagonist is referred to interchangeably as suparná- and śyená-, suggesting either an identity or a partial semantic overlap between the meanings of these words. "s'yená- (Avestan saêna-) is usually rendered either as "falcon", "eagle", or "hawk". ${ }^{23}$ Ulrich Schneider ${ }^{24}$ has put forward strong arguments for identifying the bird of RV 4.2627 as a falcon; arguing, first, that the śyená- - whose speed and courage are praised in these hymns - seizes the soma from its guardians in the way a raptor snatches its prey; ${ }^{25}$ second, that falconry is described in these hymns. H.-P. Schmidt, while refraining from identifying any particular species as the śyená-/ saenna-, has brought the validity of the latter argument into question, pointing out that other raptors may be used for falconry and that Ktesias actually mentions the Golden Eagle being used for this purpose by the Indians. ${ }^{26}$ Frits Staal, ${ }^{27}$ who bases his conclusions on the form of the syena-shaped fire-altar in the Agnicayana rite (which suggests a bird with a wide wingspan but short tail-feathers), thinks of a vulture, opting for the Himalayan Griffon (Gyps himalayensis). ${ }^{28}$ None of these suggestions

${ }^{21}$ The dictionaries typically list a number of birds of prey as possible candidates; cf. e.g. Böhtlingk \& Roth, s.v. suparna: "ein best. grosser Vogel, Raubvogel: Adler, Geier".

${ }^{22}$ In later Vedic times, a distinction seems to be made; cf. Bṛhadāraṇyaka Upanișad 4.3.19: śyeno vā suparno vā.

${ }^{23}$ The dictionaries are inconclusive: "Raubvogel, Falke" (Mayrhofer); "Adler; auch Falke oder Habicht" (Böhtlingk \& Roth); "der grösste und stärkste Raubvogel, wol ursprünglich der nach seiner röthlich-weissen Farbe benannte Lämmergeier, aber auch wol in allgemeinerem Sinne Adler, Falke" (Grassmann). "The later Indo-Iranian languages in which the word is preserved show the meanings 'falcon' and 'hawk', but also 'kite', and in Simhalese we find three meanings: 'falcon', 'eagle', and 'kite' ... The Indian evidence, even if it were unambiguous, would not be probative for Iranian since etymologically identical names often refer to different animals in different languages" (Schmidt 1980, p. 16).

${ }^{24}$ Schneider 1971, pp. 31-7.

${ }^{25}$ In the Middle Vedic śyena rite, a form of black magic (abhicāra-), the sacrificer "seizes" his enemy "like a śyena seizes [its prey]" (yathà śyena ädadìta). (ȘvB 4.2.3.)

${ }^{26}$ Schmidt 1980, p. 16.

${ }^{27}$ Staal 2010 [1983], pp. 88-90.

${ }^{28}$ One might compare Staal's illustrations showing the outlines of the fire-altar with the vulture's silhouette in Ali 1955, pl. 67. 
is conclusive; the only thing certain is that the word denotes a bird of prey, but it may not refer any single species, nor is it certain that its meaning is identical with that of suparná-. "Bird of prey" may then be the best tentative translation of both these words.

However, another interpretation of suparná-, based exclusively on RV 1.164.20-22 quoted above, holds that a bird of prey, at least in these verses, cannot be meant, as birds of prey don't eat fruit. This fact was pointed out by Thieme, who, however, argued that we "dürfen ... nun nicht vollständige zoologische Genauigkeit erwarten", ${ }^{29}$ and preferred to render suparná- as "Adler". In a lengthy discussion, Johnson ${ }^{30}$ has attempted to identify the suparná- of the riddle as a tree-inhabiting, frugivorous bird with handsome plumage; he opts for the Golden Oriole.

It appears, in conclusion, that suparná- does not signify any particular species of birds - being used for raptors as well as fruiteaters - but rather "may be taken as one of the synonyms for bird, such as ví, garútmat" ${ }^{31}$ As it seems futile to try to narrow down its meaning more than that, the word will be rendered simply as "bird" throughout this paper.

\footnotetext{
${ }^{29}$ Thieme 1949, p. 59. In support of his view that the word denotes an eagle, Thieme adduced the beautiful plumage of this bird, and the fact that eagles often hunt and are seen in pairs.

${ }^{30}$ Johnson, op. cit., chap. 3. Johnson partly bases his conclusions on a conference paper by K. N. Dave. While this was not accessible to me, a discussion of the word suparná- which appears to be pretty much the same as the one referred to by Johnson is included in Dave's book Birds in Sanskrit Literature (2005 [1985]), pp. 72-5. One of Dave's arguments is that the word sayúja in 1.164.20 must mean two pairs of birds, which would fit the oriole; this bird often builds its nest in a tree beneath the nest of a bird of prey, whose presence keeps potential attackers away. The two pairs would then be a male and a female oriole and a male and a female eagle or other bird of prey; this latter couple is described as "watching" because they "guard" the tree. Johnson (pp. 50-1) rightly criticizes these arguments, rejecting Dave's reading of sayúja as two pairs as well as citing ornithologists to the effect that orioles do not, in fact, build their nests beneath eagles' nests.

${ }^{31}$ Houben, op. cit., p. 521 (who sees Johnson's oriole as the most likely candidate in the case of RV 1.164.20-22).
} 


\section{Thieme's view: the two birds and the moon}

The "riddles" of the Vedic hymns are, as has long been recognized, ${ }^{32}$ based on poetical images and phrases current in the priestly circles for which the riddles were probably intended; so that the answer to a riddle would quickly suggest itself to someone sufficiently familiar with this phraseology. For a modern researcher, this means that a solution sometimes becomes possible through the recurrence of an image in another hymn, perhaps in a less cryptic context. Using this kind of method, Thieme ${ }^{33}$ was able to build an impressive case for the tree in RV 1.164.20-22 being the world-tree or axis mundi; the figs, the light of the firmament - identified with soma and the ambrosia (amrta-) of the gods ${ }^{34}$ - which is absorbed by the moon and causes it to swell; the two birds, the waxing and waning moon; and the several "unblinking" birds, the stars. (A very similar, though less thoroughly argued, interpretation had in fact been suggested by Hillebrandt. ${ }^{35}$ ) Though it is hard to do justice to Thieme's argument in the limited space at our disposal, the following summary should, I think, bring out the most essential points: the "mighty guardian of the whole world", who is "wise, inspired" (dhíra-) and is said to "enter" the poet in st. 21, is identified as Soma who, as the sacred beverage, "enters" and inspires the poet; the verb $\bar{a}$ - viś- ("to enter") being typically used in connection with the consumption of Soma (who is also characterized as dhitra-) by gods or men. ${ }^{36}$ The "honey" on which the

\footnotetext{
${ }^{32}$ Cf. e.g. Gonda 1975 , pp. 132-35.

${ }^{33}$ Thieme 1949.

${ }^{34}$ On the equation of amrita- and light, see Thieme, op. cit., p. $63 \mathrm{ff}$.

${ }^{35}$ Hillebrandt (1913, p. 105) saw the two birds as sun and moon (the latter being identical with Soma); Soma is the one who has "entered" the poet as the sacrificial drink in st. 21; the plurality of birds are the stars, which are identical with the Ancestors who have gone to heaven. No interpretation of the "fig" is given here; elsewhere, (Hillebrandt 1999: I, p. 441 n. 240) he identified it as the soma that is drunk by the Ancestors. This time, however, he had to leave out st. 20 completely from his interpretation; perhaps he ran into difficulties when trying to hold on to his identification of the one fig-eating bird as the moon/Soma, as the image of Soma the bird eating Soma the fig would be a farfetched one.

${ }^{36}$ Thieme, op. cit., p. 66. (The "Father" mentioned in st. 22 may likewise be Soma (cf. above); no one who does not know him gets to taste the "sweet fig".) On the verb $\bar{a}$ viś- used in connection with soma, cf. also Smith 2009, p. 179ff, who notes that it may refer both to the actual beverage entering its consumer, and the divine Soma "possessing" (this being one meaning of $\bar{a}$ - viśs-) a person through the drink. The poets
} 
many birds feed is likewise the soma, which, of course, is frequently denoted by the word mádhu-, as well as amŕta-.

In post-Rgvedic texts, Soma is, of course, identified with the moon; it is said to be gradually consumed by the gods in the dark half of each month, causing the moon to wane. ${ }^{37}$ In the RV there is, however, only one undisputed occurrence of the identification of Soma with this luminary: the "wedding hymn", 10.85, which is considered to be one of the very latest texts of the RV. Thieme does not suggest that the moon is already identified with Soma in 1.164.2022 , asserting that the connection between the two is of a different kind here: "Jedenfalls hat der Soma die gleiche Beziehung wie zum Mond in unserm Vers auch zu den Sternen. Auch sie speisen sich von dem lebendigen Himmelslicht, d. h. dem Soma." ${ }^{38}$ Yet the waxing of the moon through absorption of the divine liquid, as he depicts it, certainly is a conception that belongs to the later Soma/Moon mythology.

The bird eating the fig is, according to Thieme, the waxing moon, feeding on the light of heaven; the bird that merely looks on is the waning moon. The word suparná- is, as Thieme notes, frequently used to denote heavenly luminaries in the RV, and especially the sun; at least in 1.105.1 it is, however, used for the moon: "The moon courses as a bird in the [heavenly] waters" (candráma apsv àntár $\stackrel{a}{a}$ suparnó dhāvate divi). More direct evidence can be found in the undeniable similarities between 1.164.20-22 and the stanzas 10.114.3-

\footnotetext{
inspired by the soma-juice are, in a sense, possessed by the deity Soma. Such a meaning would fit very well to the passage 1.164.21.

${ }^{37}$ Reference may be made to Gonda 1985, p. 44ff; Hillebrandt 1999: I, p. 195ff; and especially Wilden 2000, pp. 77-94. Why Soma came to be identified with the moon remains one of the great riddles of early Vedic religion, and is a question that cannot be discussed at length here; see Gonda, op. cit., for a summary of views. In RV 8.82 .8 , however, soma (i.e., the soma-stalks) soaked in water is compared to the moon in the (heavenly) waters (yó apsú candrámā iva sómaś camúsúsu dádrśe); and it is possible that such comparisons eventually led to an identification between the two. The act of swelling ( $p y \bar{a}-)$ is common to them both (the waxing moon; the dried soma-stalks swelling when placed in water), and this analogy (cf. AV 7.81.6; Wilden, p. 76) is perhaps implied already in the image in 8.82 .8 . The attribution of immortality and the ability of rejuvenation to the moon may also have been a factor, as soma, too, was said to bestow vigor and "immortality"; thus 10.85 .19 (discussed below) states that the moon - here identified with Soma - prolongs the life of the gods.

${ }^{38}$ Op. cit., p. 66.
} 
5, to which $\operatorname{Haug}^{39}$ was the first to draw attention and which, though any affinity between the passages was promptly dismissed by Geldner, ${ }^{40}$ were again discussed by Thieme. I provide the following translation, which does not differ in any significant way from those of most translators:

A young woman having four plaits, beautifully adorned, with ghee on her face, clothes herself in coverings (?). ${ }^{41}$

Two male birds have settled on her, where the gods have received their share.

The one bird has entered the ocean; he surveys this entire world.

With an immature mind, I watched him close by. The mother licks him, and he licks the mother.

The bird, being one, the priests, the seers, arrange with words in many ways;

making verses at the sacrifices, they measure out the twelve cups of soma. ${ }^{42}$

The dependence of parts of these verses on 1.164.20-22 is fairly certain, as Thieme makes clear. The image of two birds perched on a young woman seems to be the result of a not completely successful transposition of the image in 1.164.20. Words and phrases from 1.164 are easily recognized, though somewhat modified: the páka- mánas("immature mind") of the poet, reminiscent of the admission of being an ignorant (pák ka-) in 1.164.21; the mention of the "share of the gods" (cf. the "share of amrta-" in 1.164.21); and the stanza 1.114.5, based on 1.164.46. The reference to the gods' having received their share suggests a distribution or portioning out, as mentioned in 1.164.21 (vidatha-). The identity of the single bird with Soma is clearly brought out here: the bird is multiplied by the priests, who measure out the

\footnotetext{
${ }^{39}$ Haug, op. cit., pp. 481-82.

${ }^{40}$ Note to RV 1.164.20-22: "Etwas anderes sind die beiden suparnă in 10, 114, 3".

${ }^{41}$ On vayúna- cf. Thieme, op. cit., pp. 13-25.

${ }^{42}$ cátuṣkapardā yuvatíh supéśa ghrtápratīkā vayúnāni vaste / tásyām suparṇá víṣaṇā ni ședatur yátra devá dadhiré bhāgadhéyam //

ékah suparṇáh sá samudrám á viveśa sá idạm viśvam bhúvanam ví caște / tám pákena mánasāpaśyam ántitas tám mātấ reḷi sá u reḷhi mātáram //

suparnám vịprāh kaváyo vácobhir ékam sántam bahudhá kalpayanti / chándāmsi ca dádhato adhvaréṣu gráhān sómasya mimate dvádaśa //
} 
sacred drink in twelve cups. It should be noted that these twelve do not seem to have any factual correspondence in the ritual: rather, they should be understood as the months of the year, which are indeed "measured out" by the moon. ${ }^{43}$ The "share of the gods" or "share of amrta-", located where the birds nest, or at the top of the tree, can also be identified as the sacrificial drink; amrta-, the "ambrosia" of the gods, is often identified with soma. ${ }^{44}$ The ocean which the "one bird" has entered is the heavenly waters. The "young woman" is, in Thieme's interpretation, the night sky; he assigns the same meaning to the crown of the tree in 1.164.20-22. We will take a look at his arguments for this identification later on.

The two birds, then, would in fact be two aspects of one and the same luminary, which would explain why the stanzas 1.114.4-5 go on to speak of the "one bird" as a single entity. The fig-eating bird being the waxing moon, it seems plausible that the waning moon could be described as "non-eating", in which case its shrinking would perhaps be implied as a result of this fasting. As to the mention of its "watching", it is not immediately clear in what way this would be a characteristic of the waning moon. Thieme understands the verb abhi cākasititi to mean that the bird faces and watches the eating bird. The opposed conclaves of the waxing and the waning moon could, though they are not simultaneously seen, conceivably be pictured as two birds facing each other on a tree-branch. It is, however, not certain that the non-eating bird looks at the other bird; and a different line of interpretation is possible.

It was Kuiper ${ }^{45}$ who, while agreeing with Thieme's interpretation of the tree as the "world-tree", pointed out the similarities between, on the one hand, the stanzas RV 10.85.18-19, and, on the other, 1.164.20-22 and 10.114.3-5, quoted above. The verses may be translated as follows:

\footnotetext{
${ }^{43}$ The moon is frequently said to "measure out" ( $\left.m \bar{a}-\right)$ the months; the verbal root used in this context recurs in the word for "moon", mása- (later candramás-, "the shining más-"), as well as in máhh, "month".

${ }^{44}$ Cf. Gonda 1985; Lommel 1978, pp. 314-23. On the word amrta- (lit. "immortality", but usually in the sense of prolonged, rather than eternal, life), and its relationship to the Greek ambrosia, see Thieme, op. cit., p. 64ff; 1968; and cf. Gonda, op. cit., p. $61 \mathrm{ff}$.

${ }^{45}$ Kuiper 1983, p. 126.
} 
These two move, one after the other, ${ }^{46}$ by means of their wondrous power; two playing children wander about the sacrifice.

One surveys (abhicáșța) all creatures, the other, apportioning the seasons, is born again.

He becomes ever new as he is born; he walks in front of the dawns as the sign of the days.

As he comes, he apportions the share (bhāgám) to the gods. The moon prolongs life, [making it] long. ${ }^{47}$

This is the only hymn in the RV in which the identification of Soma and the moon is indisputable. The notion that it apportions the "share" of the gods, prolonging life, foreshadows the conception of the moon as a vessel containing the sacred drink; no doubt the moon's being "reborn" again and again, as mentioned in these verses, was one of the reasons for its identification with the immortality-bestowing drink of the gods. The two birds in 10.114.3 are said to be perching "where the gods receive their share" (yátra devà dadhiré bhāgadhéyam); in 1.164.21, the (many) birds shriek for the "share of amrta-" (amritasya bhāgám), "for the distributions" (vidáthā). As is well known, the amrta- or ambrosia is often identified with soma, and though the word is not explicitly mentioned in $10.85 .18-19$, the notion that the "share of the gods" prolongs life is a clear indication of what is meant. In 1.164.22, the birds seeking the amŕta- are described as madhvádah, "honey-eating", the "honey" (madhu) most likely being soma, which is often referred to by this word. The "sweet fig" (pippalam $s v \bar{a} d v$ ) at the top of the tree must be the same.

\section{Sun and moon}

Kuiper sees the pair described in 10.85.18-19 as the sun and the moon, and though the sun is not expressly named, the same view has been held by most translators (as well as Sāyana). ${ }^{48}$ There is no indication

\footnotetext{
${ }^{46}$ Following Oldenberg 1909-12: II, p. 288.

${ }^{47}$ pūrvāparám carato māyáyaitaú síśū krịlantau pári yāto adhvarám / viśvāny anyó bhúvanābhicáșta rtứmir anyó vidádhaj jāyate púnah //

návo-navo bhavati jấyamānó 'hnām ketúr ușásām ety ágram / bhāgám devébhyo ví dadhāty àyán prá candrámās tirate dīrghám à̃yuh //.

${ }^{48}$ E.g. Geldner (cautiously), O'Flaherty, Jamison \& Brereton.
} 
that the one who "surveys all creatures" would be an aspect of the moon; in fact, omnivision is a typical characteristic of the sun in the Vedic hymns. As already mentioned, suparná-, too, is especially often used to denote the sun. ${ }^{49}$ With this in mind, it is perhaps a bit odd that no one, at least to my knowledge, has ventured to compare the onlooking bird in 1.164.20 with other instances in which a suparná- is described as watching or seeing; especially as there are several such occurrences in the RV. One example is 1.35.7, part of a hymn to the solar deity Savitr, which describes the nocturnal movements of the sun:

The bird (suparnó) has looked across (vi ... akhyad) the middle realms of space, the deeply inspired, lordly one, having good guidance.

Where is the sun now? Who has understood it? To what heaven has its ray extended? $?^{50}$

Soma, whose connection with the sun antedates that with the moon, ${ }^{51}$ is significantly described in very similar words in passages where this identity or connection is stressed: ${ }^{52}$

Like an ox walking around the herds has he roared, having assumed the brilliance of the sun.

The heavenly bird (divyáh suparnó) looks down ('va cakșata) upon the earth; Soma surveys the beings through his power. ${ }^{53}$ (9.71.9.)

As a heavenly bird, look down (divyáh suparnó 'va cakṣi), Soma, making the streams swell through your activity at the sacrificial rite of the gods.

Enter, o Indu, the soma-containing vessel; go, roaring, to the ray of the sun. ${ }^{54}(9.97 .33$. $)$

\footnotetext{
${ }^{49}$ The RV and AV passages where this or other words for "bird" (e.g., patamgá-) denote the sun were collected by Kirfel 1967 [1920], pp. 18-19.

${ }^{50}$ ví suparnó antárikṣāny akhyad gabhīrávepā ásurah sunītháh / kvèdànīm sūuryah káś ciketa katamám dyà mạ raśmír asyà tatāna //.

${ }^{51}$ Cf. Lüders 1951, pp. 256-68.

${ }^{52}$ Cf. the discussion of these passages by Roesler 1997, p. 207 (the soma-juice poured out in the vessel being "macrocosmically" united with the sun).

${ }^{53}$ ukșéva yūthá pariyánn arāvìd ádhi tvișìr adhita súrryasya / divyáh suparnó 'va cakṣata kṣáṇ sómah pári krátunā paśyate jăh //.
} 
Cf. also AV 13.2.9c-d: "The heavenly bird, the hero, Aditi's son, has surveyed all beings"; 55 and $13.3 .1 \mathrm{c}-\mathrm{d}$ : "... in whom the directions reside, the six wide [regions], along which the bird (patangá-) looks out". ${ }^{56}$ Both passages appear in hymns to Rohita, the "ruddy", rising sun. In AV 7.41.1-2, the "bird of prey surveying mankind, watching the dwelling-places" (śyenó nrcákșā avasānadarśáh, st. 1), the "bird of prey, surveying mankind, the heavenly bird with a thousand feet, a hundred wombs, bestowing strength" ${ }^{57}$ (st. 2), likewise appears to be the sun. ${ }^{58}$

If the bird in 1.164.20 is the sun, the mention of its "watching" may, then, refer to its surveying the world from the crown of the cosmic tree (i.e., heaven), rather than looking at the other bird.

In the hymn 1.164 itself, the sun is once characterized by its vision, although it is not called a bird. The passage is st. 44, which, though seemingly obscure, has long been convincingly and more or less unanimously interpreted:

Three long-haired ones appear in season. One of them shaves in the course of a year; one looks out over everything through his powers; of one, the onrush can be seen, not the form. ${ }^{59}$

The one who "shaves" is Agni, who is elsewhere said to "shave" the "hairs" or "beard" of the earth (i.e., vegetation) in the form of forestfires during the hot season. ${ }^{60}$ The one whose onrush can be seen, but not his form, is the Wind, who is described with almost identical words in 10.168.4. The three "long-haired ones" are thus Fire, Wind and Sun, the deities of the three "worlds" (earth, atmosphere, and sky, respectively), who form a triad already in RV but rise to prominence

\footnotetext{
${ }^{54}$ divyáh suparnó 'va cakṣi soma pínvan dhấrāh kármaṇa devávītau / éndo viśa kaláśam somadhắnam krándann ihi súryasyópa raśmím //.

${ }_{55}$ divyáh suparnáh sá vīró vy àkhyad áditeh putró bhúvanāni viśsā.

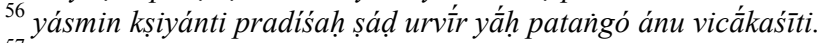

57 śyenó nrcákșā divyáh suparnáh sahásrapāc chatáyonir vayodháh.

${ }^{58}$ In 13.2.38, 3.14, Rohita is described as a yellowy goose (hamsá-) who "goes, surveying all beings" (sampáśyan yāti bhúvanāni viśvā).

${ }^{59}$ tráyaḥ keśina ro ruthá ví cakșate saṃvatsaré vapata éka eșām / víśvam éko abhi caște śácībhir dhrấjir ékasya dadrśse ná rūpám //.

${ }^{60} 1.65 .8,10.142 .4$; cf. TB 1.5.6.5. This is also how Yāska (Nirukta 12.27) and Sāyaṇa explain the passage.
} 
in the speculations of the Middle Vedic ritualists. ${ }^{61}$ The meaning of the designation "long-haired" (keśin-) is not entirely clear; according to tradition, the "hair" of fire and sun is their flames and rays, that of the wind, lightning. ${ }^{62}$

We also have a number of mentions of one or several suparna-s in this hymn; and though only the one in st. 20 is said to be "watching", it is obvious that any interpretation of the "two birds" should take these other mentions into consideration. ${ }^{63}$ The last stanza of the hymn, $52,{ }^{64}$ speaks of a single suparna-:

The heavenly suparna-, the lofty bird (vāyasá-), the beautiful embryo of the waters, of the plants;

Sarasvant, who satisfies with rains ... do I invoke for help. ${ }^{65}$

The bird here is to be sought in heaven, as is clear from the adjective divyá- as well as from its giving rain (which explains the epithet sárasvant-, "rich in pools"). This is well in keeping with the Vedic notion of the sun as the source of rainfall, ${ }^{66}$ and the bird in this stanza has usually been interpreted either as the sun or Agni, or both. ${ }^{67}$ The

\footnotetext{
${ }^{61}$ Cf. in general Macdonell 1897, pp. 19, 93.

${ }^{62}$ Brhaddevatā 1.94. Agni's "hair" - flames - is sometimes referred to, and it seems likely that the passage seeks to promote the idea that these deities are three "fires" distributed over the worlds. This idea is frequently met with in the Brāhmanas, where we also find attempts at explaining how wind could be a form of fire (Klaus 1986, pp. 89-91).

${ }^{63}$ Cf. O'Flaherty 1981, who seems to take them all to be one and the same bird: "The most explicit and developed contrast is between the two birds (20-22), who occur in other forms as well, as an individual bird $(7,46,52)$ and a group of birds $(21,47) \ldots$ " (p. 73); "That the bird in the hymn is the sun or fire is a conjecture supported by many explicit references to the sun-bird in the Rig-Veda (cf. 10.123, 10.177) and by references to the sun in this hymn $(14,26)$." (P. 74.) Similarly Houben, op. cit., p. 521: "Elsewhere in our hymn, either the sun (vss. 46, 52) or the sun's rays (vs. 47) are called suparná. Moreover, in $7 \mathrm{~b}$ vi refers to the sun as a bird ..."

${ }^{64}$ The stanzas 48-52, which deal with the origins of rainfall, may however be a late addition to the hymn, as appears from the fact that they are not included in the AV, where the riddle-hymn is found (divided in two parts) as hymns 9.9 (corresponding to RV 1.164.1-22) and 9.10 (corresponding to 23-47). Cf. Brown, op. cit., pp. 201-2.

${ }^{65}$ divyám suparnám vāyasám brhántam apām gárbham darśatám óṣadhīnām / abhīpató vrșțibhis tarpáyantam sárasvantam ávase johavīmi //.

${ }^{66} \mathrm{Cf}$. Wilden 2000, chap. I.

${ }^{67}$ The sun: Haug, op. cit., p. 514; fire: Macdonell, op, cit., p. 88 (following Bergaigne); sun and fire: Brown, op. cit., p. 218; Geldner ad loc., and cf. O'Flaherty, op. cit., pp. 73-4.
} 
words, "embryo of the waters, of the plants" point to Agni, who is often said to be lodged in the plants or the waters, from which he is "born"; ${ }^{68}$ indeed, Agni is described with the very same words (apám gárbham darśatám óṣadhīnām) in 3.1.13. The bird is likely to be both Sun and Fire, which are not infrequently equated. The fact that both are intimately connected with rainfall ${ }^{69}$ further supports this interpretation.

The "heavenly feathered bird" (divyáh sá suparnó garútmān), mentioned among a number of other deities in st. 46, is also apparently the sun. In the following stanza (47), several birds are mentioned:

Along the black path, the yellow birds, clothing themselves in waters, fly up to heaven.

When they have returned from the seat of Rita, the earth becomes soaked with ghee. ${ }^{70}$

The birds have been interpreted either as the flames of the sacrificial fire, rising along the "black path" of the smoke, or as the rays of the rising sun extending through the nocturnal darkness. ${ }^{71}$ I believe a

\footnotetext{
${ }^{68}$ The designation "embryo of the waters" (apăm gárbha-) seems to be exclusive to this god: RV 1.70.3, 3.1.12, 3.5.3, 7.9.3 (Agni Jàtavedas as the rising sun). Only once (9.97.41) is it used for another deity, here Soma, who is perhaps compared to Agni; the "waters" here would be the waters with which the soma-juice is mixed, and which correspond to the heavenly waters where the divine Soma dwells. Cf. further Agni as "gárbha- of the plants (óṣadhi-, vìrúdh-)": 2.1.14, 7.101.1, 102.2.

${ }^{69}$ Rain was thought to fall from the sun in the earliest Vedic times (for the RV cf. Lüders 1951, chap. IX); in post-Rgvedic times the role as rain-bringer was variously assigned to the sun and to the moon (now identified with Soma). I refer to Wilden's detailed study of the subject.

${ }^{70}$ krșnám niyánam hárayaḥ suparnáa apó vásānā dívam út patanti / tá ávavrọtran sádanād rtásyấd íd ghrténa prthivì vy ùdyate //. On this stanza and its variants in Atharvaveda and the Yajurvedic Saṃhitās, cf. Wilden, op. cit., pp. 95-6.

${ }^{71}$ Brown, op. cit., p. 210: "Now the hymn turns to the Sun's rising. The rays, here called 'yellow birds,' clothed in the waters, fly up along the dark path (of night) to the sky." Geldner ad loc.: "Die schwarze Bahn ist der Rauch, die goldfarbigen Rosse (sic) die zum Himmel fliegenden Flammen." Haug, op. cit., p. 510: "Der schwarze Pfad ist die Nacht, wie schon Yâska erkannte (Nir. 7, 24 wo der Vers erklärt ist); die gelben Adler ... sind die Sonnenstrahlen; sie hüllen sich in Wasser, weil sie die Eigenschaft haben, gerade das Wasser anzuziehen, das dann im Regen, hier 'zerlassene Butter' genannt, herabfällt." Lüders (op. cit., p. 312) likewise follows Yāska, whose interpretation is echoed by later exegetists (cf. Sāyana: the sunrays rising through the darkness of the night). Wilden (loc. cit.) does not pass judgement on the matter.
} 
double meaning is intended, and that the birds can be seen as flames as well as sun-rays; ${ }^{72}$ the sun and the sacrificial fire being homologous. The "seat of Rta" is, cosmologically, the place whence the Dawn rises each morning ${ }^{73}$ on the terrestrial plane, it may conceivably designate the site of the sacrifice. The "ghee" is, of course, rain, thought to originate in the oblations thrown in the sacrificial fire, from which they rise up to the sun and turn into rainwater. ${ }^{74}$

If other words with the meaning "bird" should be taken into account, we may also have a look at st. 7, which has been held forth by Houben ${ }^{75}$ as a key to the understanding of the riddle of the two birds. The one bird (vi-) here is most likely the sun:

Let him speak who here knows the laid-down footprint of this dear bird ... ${ }^{76}(1.164 .7 \mathrm{a}-\mathrm{b}$.

The "footprint of the bird"77 (padám véh) appears elsewhere as, it seems, the highest point of heaven, to which the inspired thoughts of the poets are directed (e.g., 3.5.5-6, 3.7.7, 4.5.8, 10.5.1). That the

\footnotetext{
${ }^{72}$ The suparnás seated in heaven in 1.105.11 (suparná etá āsate mádhya āródhane diváh) are likewise taken by most translators to be the rays of the rising sun.

${ }^{73} 4.51 .8$; compared to 1.164 .47 by Kuiper 1983, p. 80 n. 122 .

${ }^{74} \mathrm{Cf}$. Wilden's monograph on the Vedic "Kreislauf der Opfergaben". The conception is described with unusual clarity in the penultimate stanza of the "riddle hymn", 1.164.51: "This same water travels upward and downward as the days pass; the rainclouds invigorate the earth, the fires invigorate heaven". (samānám etád udakám úc caíty áva cáhabhị̣ / bhúmim parjányā jínvanti divam jinvanty agnáyah //.)

${ }^{75}$ Op. cit., p. 517.

${ }^{76}$ ihá bravītu yá ìm angá védāsyá vāmásya níhitam padám véh /.

${ }^{77}$ The meaning of padá- in "esoteric" contexts like the present one has been a matter of some dispute; it is usually rendered as "footprint", "track", "step", or "place". Lüders (1951, pp. 303-5), who discussed the matter at length, opted for "Stätte", rejecting Geldner's translation "Spur" on the grounds that a bird flying in the air does not leave any footprints. I suspect, however, that this is an intended paradox; the "footprint of the bird", invisible to the human eye, can only be perceived by the inspired seers in their visions. Renou (1958, p. 21-2) sees a primary meaning "footprint", which is also to be understood in passages speaking of the padá- of the bird or the "hidden padá- of the cow" (which in some passages explicitly refers to the tracking down of a herd of cattle by means of their footprints). "Padá- est donc d'abord l'empreinte des pieds, la trace au sens propre ... La «trace de l'oiseau», au sens propre le trajet solaire, a des implications ésotériques" (ibid.). Mayrhofer (s.v.) rejects the meaning "Stätte" altogether in the RV; cf. however Houben, op. cit., p. 515 n. 87.
} 
"bird" is the sun can hardly be doubted. ${ }^{78}$ What is unusual with 1.164.7 is the expression "of this dear bird" (asyá vāmásya ... véh). The occurrence of the words asyá vāmásya elsewhere in the same hymn - in st. 1 - cannot be ignored or considered coincidental, as these are the only two occurrences of these exact words in the RV. The stanza 1.164.1 runs as follows:

This dear grey hotr-priest has a middle brother who is hungry, and a third brother with ghee on his back. I have seen here the leader of the tribe with seven sons. ${ }^{79}$

The two main lines of interpretation have seen the three brothers either as forms of Agni distributed over the three cosmic regions, or as the three fires of the Vedic sacrifice. ${ }^{80}$ The latter interpretation, which was put forward by Geldner, seems the most probable; there is nothing in the stanza to suggest a cosmic nature of the three (the word áśnah here meaning "hungry, ravenous", not "lightning"81), and the designations "grey" (referring to smoke) and "ghee-backed" (elsewhere applied to Agni as the sacrificial fire ${ }^{82}$ ) are best taken to refer to actual fires. But as we have seen, the present hymn knows the speculation equating the fires of the sacrifice with the three deities of the cosmic regions (i.e., the three "forms" of Agni), and this identity

${ }^{78}$ Cf. Lüders, op. cit., pp. 300, 303-5, 311 .

${ }^{79}$ asyá vāmásya palitásya hótus tásya bhrấtā madhyamó asty áśnah / tritíyo bhrátā ghrtáprsștho asyắtrāpaśyam viśpátim saptáputram //.

${ }^{80}$ The view that they represent sun, lightning, and the terrestrial fire was put forward by Haug, op. cit., p. 466, and was largely accepted by Brown, op. cit., p. 210 (who, however, held the first brother to be "the original form of Agni as "firstborn of the rtá", rather than the sun). Hillebrandt (1999: I, p. 86; cf. 1913, p. 104 n. 1) takes them to be sun, moon, and fire, represented on earth by the three fires of the sacrifice; the "grey" one is the moon and the "eater" the sun (which is in the Brāhmanas said to "devour" the moon at a lunar eclipse). Kunhan Raja, op. cit., p. 7, following Yāska, takes them to be Sun, Wind, and Fire, the deities of the three cosmic spheres. Houben, op. cit., p. 518, suggests Sun, Lightning, and the Gharma pot. Geldner's view, that the verse refers to the traditional three fires of the sacrifice, has been repeated by O'Flaherty and Witzel, Gotō et al., while Brereton and Jamison (in their introduction to 1.164) recognize that the two lines of interpretation are not mutually exclusive; ritual and macrocosm being mysteriously connected and equated with each other.

${ }^{81}$ As it was rendered by Brown, op. cit., p. 210 (on analogy with aśani-, or with aśan, "stone (used as a projectile)"?). The dictionaries of Grassmann as well as Böhtlingk \& Roth give 1.164 .1 as the only instance where áśna- ("Gefrässig") is used "vom Blitzfeuer"; this is of course simply their own interpretation of a difficult passage.

${ }^{82}$ E.g. in $5.4 .3,14.5 ; 7.2 .4 ; 10.122 .4$. 
seems to be implied by referring to the sun (the "dear bird") with the same words as one of the fires. Now, in Middle Vedic speculations, the gārhapatya fire corresponds to Agni and the earth, the dakșināgni to Wind and the atmosphere, and the ahavaniya to the Sun and heaven. Whether this system was already developed or not in late Rgvedic times, the homology of fire and sun is certainly Rgvedic, and it seems likely that an identification of one of the three fires with the sun is implied in st. 7 .

Houben ${ }^{83}$ has put forward the view that, as one of the three "brothers" seems to be the sun described as a bird, it is reasonable to assume that the other two are also birds. He also suggests that the two birds of the riddle in fact belong to this set of three. Houben, whose objective is to demonstrate that a larger part of the hymn than previously thought centers around the Pravargya rite, suggests an identification of the "ghee-backed" brother with the gharma pot, the inside of which was anointed with ghee. ${ }^{84}$ The "dear, grey" brother is, he suggests, the sun, the cosmic counterpart of the heated pot. The "middle" brother would then have to be situated somewhere in between these two, the terrestrial and the celestial brothers. Houben believes that this must be either wind or lightning, and opts for the latter alternative, taking the word áśna- ("ravenous") to refer to the violent action and sound of lightning. The two birds are, he further suggests, "the two more immediately perceptible of the three birds of verse 1, viz., the sun and the Gharma pot; lightning, the elusive middle one, is left out" ${ }^{85}$ While noticing that the "hungry" or "ravenous" brother would make an attractive correspondence to the bird that "eats" the fig, Houben ultimately has to reject such a connection in order to maintain his view that the "middle" brother has been excluded in st. 20. Though he briefly notes that seeing or watching is a typical characteristic of the sun ${ }^{86}$ he also dismisses the idea that the watching bird would be the sun, instead suggesting that this should be the eating bird, who (here he follows Thieme) feeds on the light of heaven. The non-eating, watching bird, then, is the Gharma pot, the terrestrial counterpart of the sun.

\footnotetext{
${ }^{83}$ Op. cit., p. 521.

${ }^{84}$ Op. cit., p. 517.

${ }^{85}$ Houben 2000 , p. 521 ; italics in original.

${ }^{86}$ Op. cit., p. 521 n. 115.
} 
While some verses of the hymn certainly concern the Pravargya, no such connection is immediately clear in either st. 1, 7, or $20-22 .{ }^{87}$ As has already been said, the interpretation of the three brothers as the sacrificial fires still seems the most probable one. The question still remains which of the three should be identified with which fire. The "dear" one which, as we have seen, is equated to the sun, would be the Āhavaniya; the "middle" one can hardly be any other than the southern fire, which occupies an intermediate position in relation to the other two. The remaining fire, that with "ghee on his back", would then be the Gārhapatya or domestic fire. Now, why would the Dakșināgni be referred to as "hungry, ravenous", and what would be its connection to the second bird of the riddle, assuming that the other is the sun and corresponds to the Āhavanīya? We have suggested that the two birds are the sun and the moon. The Dakṣināgni is shaped like a half-moon. In the brahmanical system of mystic "correspondences", it is usually equated to the Wind and the atmosphere; but another tradition makes it the counterpart of the moon. ${ }^{88}$ Besides its shape, one reason for this identification is the connection between this fire and the cult of the Ancestors, who receive their oblations through it; the world of the Ancestors is in

\footnotetext{
${ }^{87}$ On Houben's approach, cf. the (generally approving) remarks in Jamison and Brereton's introduction to RV 1.164; and the harsher comments in Oberlies 2007 (throughout the footnotes). Whatever part the Pravargya may play elsewhere in the hymn, Houben's interpretation of 20-22 seems to me particularly open to question. Houben maintains (p. 522) that previous renderings of the verb pári șasvajāte in st. 20 - commonly taken to mean that the birds "clasp" the tree, i.e., perch on its branches is incorrect, and a literal translation, "embrace" (from the root $s v a j$-) is to be preferred; this would refer to the Gharma pot "embracing" the base of the world-axis (on earth), and the sun embracing it at its top, in the sky. The image of two birds "embracing" a tree (presumably, with their wings) on the ground and in the crown, respectively, is however an uneasy one. The only natural way to read the passage is to take the verb to refer, in this context, to the perching birds' clasping the tree's branches with their talons.

${ }^{88}$ Cf. Hillebrandt 1999 I, pp. 67-70. The southern fire is associated with the atmosphere (and the wind) in the vertical cosmic classification of Middle Vedic texts; and with the moon in the horizontal classification of the cardinal directions (proceeding clockwise from the east). The southern fire is hence identified variously with the wind and with the moon. (A good deal of relevant materials can be found in B. K. Smith's 1994 survey of the Vedic classifications.) The deity of the atmosphere in this system is in fact Vāyu, the Wind, who appears between Agni or Fire and $\bar{A}$ ditya or the Sun, the deities of the earth and the sky. But occasionally we do find a triad Fire-Moon-Sun.
} 
post-Rgvedic times said to be the moon. They are also said to dwell in the south; the Dakșināgni is the "southern fire".

But what about the designation áśna- in st. 1? The word is derived from the root áś-, meaning "to eat", which is also found in ánaśnan, "non-eating", used of the second bird in st. 20. The meaning "hungry" or perhaps "ravenous" can be established from 1.173.2, where a mighty noise is likened to the roar of "a hungry wild animal" (mrgó nấśno). Now, why would the Dakșināgni be designated as "hungry"? And does this really connect it with the fig-eating bird of st. 20? Does "hungry" here imply actual hunger resulting from lack of nourishment (which would better fit the "non-eating" bird), or rather voraciousness or gluttony? It has been suggested that the word is applied to the Dakṣināgni because this fire does not receive the same amount of oblations as the two other fires. ${ }^{89}$ This seems likely; but if so, any connection with the eating bird of the riddle would seem to disappear. One might argue, however, that hunger nonetheless is what unites them (and perhaps what makes the bird eat the fig, while his companion abstains).

If the two birds represent sun and moon, corresponding respectively to the Āhavaniya and the Dakșin̄āgni, the third member of the triad in st. 1 - the terrestrial Fire, as represented by the Gārhapatya - may have been excluded in st. 20 due to the cosmological context; the sun and the moon belonging to the upper regions of the cosmos, i.e., in the crown of the world-tree, while Agni's domain is earth. ${ }^{90}$

\footnotetext{
${ }^{89}$ O'Flaherty 1981, p. 81 n. 1: "The first brother is the oblation fire [Āhavanīya] with his grey beard of smoke; the second is the southern [Dakșina] fire, hungry because it seldom receives the oblation; the third is the domestic fire [Gārhapatya] that is 'fed' the butter oblation."

${ }^{90}$ It may be pointed out that a triad of suparná-s actually appears in st. 4 of the funerary hymn AV 18.4. The verses are obscure on some points: "Three birds ... are settled on the back of the lower (?) firmament, on the summit; let the heavenly worlds, pervaded with immortality (or, ambrosia), milk forth food and nourishment to the sacrificer." (tráyah suparṇá úparasya māyú nákasya prș̣thé ádhi viṣtápi śritấh / svargā loká amŕtena viștấ ișam úrjam yájamānāya duhrām /.) According to the commentary, these birds are Sun, Moon, and Fire; though there is nothing in the stanza itself to suggest this. It seems probable that they are the three sacrificial fires, which are referred to by name in 8-9; invoked as the forms of Agni Jātavedas, they are implored to conduct (through the cremation) the dead man to the heavenly world (10ff). This might explain why they are all referred to as birds dwelling in the same heaven, rather than distributed over the regions of the cosmos. This would also
} 
Something should perhaps be said of the adjective palitá-, "grey", designating the first of the three fires. The word is also used in the sense of "old", "grey-haired". ${ }^{91} \mathrm{We}$ find it sometimes applied to Agni ${ }^{92}$ and while it is possible to take it to refer to the fire's grey "hair" of smoke - indeed the adjective is applied to a smoky fire in 10.4.5b (palitó dhümáketuh) - it is not immediately clear why this particular fire, out of the three, would be characterized by its smoke. If the word instead is taken to refer to age, this would raise further questions, as the Gārhapatya, rather than the Āhavanīya, is the "oldest" fire, from which the other two are lighted. Perhaps the adjective is simply a way to indicate that the first brother is, in fact, a (sacrificial) fire, and that the same should be inferred in the case of his two brothers. ${ }^{93}$

We will now return for a while to 10.114.3, describing two birds settled on a "beautifully adorned" young woman (yuvati) with four plaits and "ghee on her face". What may this woman represent? Thieme $^{94}$ saw in this young woman, as in the tree in 1.164.20-22, a

explain why Agni is here found in heaven together with Soma and the Sun. - As for the tráyah suparnắs in $5.28 .8 \mathrm{a}$, it seems futile to try to make out what they may be from the context; the entire hymn playing with triads of various kinds.

91 "[G]rau, ergraut, altersgrau, greis" (Mayrhofer, s.v.).

${ }^{92} 1.144 .4,3.55 .9$ (where the "grey emissary", palitó dūtá, is most probably Agni), 10.4.5.

${ }^{93}$ If an unexpressed identity between the fires and the deities of the cosmic regions is to be understood - and made clear from the recurrence of words (asyá vāmásya; variants of the root $a^{\prime} s^{-}$) elsewhere in the hymn - then the adjective, though here simply referring to smoke, may have been chosen in order to make an implicit association with, e.g., a god who may be similarly designated. In this context it may perhaps be of relevance that palitá- refers to the sun in 10.55.5: "The moon (vidhú-), coursing in the company of many, being young, did the aged one (palitá-) swallow. Behold the god's mastery in its greatness: today he died, yesterday he breathed fully." (vidhự dadrānám sámane bahūnấm yúvānam sántam palitó jagāra / devásya paśya kấvyam mahitvádyá̃ mamấra sá hyáh sám āna /.) That the young and the aged or grey one are the moon and the sun has been unanimously accepted by everyone from Yāska (Nirukta 14.18) and Saunaka (Brohaddevatā 7.81) to Geldner. The moon (coursing in the company of the many stars?) is, as we have seen, repeatedly dying and born anew. According to a common view, the new moon ("being young") is swallowed by the sun, from which it then reemerges. The sun, then, is "old" as compared to the ever rejuvenated moon. This isolated occurrence should, however, be cautiously treated.

94 Thieme 1949, p. 61. 
representation of the nocturnal sky; the girl's dark hair being the darkness, the four plaits the cardinal directions, her ornaments the stars. A somewhat different interpretation was given by Kuiper, ${ }^{95}$ who saw the young woman as the axis mundi. The four plaits, he suggested, are the four rivers flowing down the slopes of the primordial mountain (which he saw as being interchangeable with the world-tree in the position of axis mundi). ${ }^{96}$

According to Taittirīya Brāhmana $\left(1.2 .1 .27 ; 3.7 .6 .4^{97}\right)$ and Āpastamba Śrautasūtra (4.5.3), where this stanza is quoted, ${ }^{98}$ the girl is the védi, the "altar" of the sacrifice, the plaits being its four corners. (The "ghee" would then be the actual ghee used in the ritual.) It is a well-known fact that the vedi in later texts is often likened to a woman due to its shape (the word vedi further being feminine). Modern scholars have treated this tradition in different ways. Accepted by Geldner, it was dismissed by Thieme, ${ }^{99}$ who must have found it incompatible with his own interpretation. Kuiper, however, for whom "it is beyond doubt that the verse refers to the vedi", notes that,

The vedi mythically represents the whole earth, cf., e.g., MS. III.8.3 $(96,6)$, KS. XXV.4 (106, 13), XXV.6 (110, 2), XXVIII.1 (152, 9), XXXI.10, (12, 8), XXIX.8 $(177,8)$, XXXVII.16 $(97,3)$, TS. VI.2.4.5, ŚB. I.2.5.7, I.3.3.9, III.7.2.1. If the yuvatí, accordingly, here stands for the primordial hill, the two birds can be equated to the wellknown two birds on the cosmic tree in RS. I.164.20 ..100

The underlying assumption here seems to be that the cosmic tree or mountain may stand for the entire world. A look at the passages in TB and Āpastamba referred to above suggests, however, another possible interpretation. The Rgvedic stanza appears here in a somewhat modified form:

A young woman with four plaits, beautifully adorned, having ghee on her face, in the centre of the world;

\footnotetext{
${ }^{95}$ Kuiper 1983, p. 142 and n. 3.

${ }^{96}$ On the four celestial streams, cf. Lüders 1951, chap. VII.

${ }^{97}$ Translated by Dumont 1961, p. 30.

${ }^{98}$ In a slightly variant form from RV 10.114.3. On the variants of this stanza in Vedic literature, cf. Bloomfield 1906, under catuhsisikhanḍa.

${ }_{99}$ Op. cit., p. 61 n. 3.

${ }^{100}$ Kuiper 1983, pp. 142-43 n.
} 
Upon (?) the two birds who have settled on her is the share of the gods. ${ }^{101}$

In Āpastamba 4.5.1, furthermore, this vedi is said to be "on the summit of heaven, in the navel of the earth" (varșman divo nābha prthivya $)$. While the Yajurvedic ritualists may have modified the stanza so as to suit their own purposes, it may nonetheless be significant that we here have an ancient tradition that places the yuvati "in the centre of the world", which, of course, is where one would first look for an axis mundi or a cosmic tree.

The adjective supéśa, "beautifully adorned", was taken by Thieme to indicate the stars adorning the nocturnal sky. ${ }^{102}$ This seems very likely, especially as the verbal root piś- is often found in connection with the star-decorated heaven. ${ }^{103}$ The night (rátrī-), sometimes personified as a goddess, is described as having been "decorated" with stars (pépiśat, 10.127.7; "like a decorated bowl", camasó ná piștó, AV 19.49.8). This use of the verbal root may be very ancient; in the Iranian Yašts we find the compound stahr.paēsah-, "star-spangled", applied to the heaven, described as Ahura Mazdāh's robe (13.3), and to Mithra's chariot (10.143). Combinations of the same Indo-European verbal root (cf. Latin pingo) and word for "star(s)" are used by ancient Greek and Latin authors. ${ }^{104}$

But would one expect to find the sun in the nocturnal sky, together with the moon? One answer is: yes, in Vedic cosmological beliefs, one may very well do so. As is well known, the sun was thought to turn its dark backside towards earth after sunset, and return

${ }^{101}$ catuhśikhaṇ̂ā yuvatih supeśā ghrtapratīkā bhuvanasya madhye / tasyām suparnāov adhi yau niviștau tayor devānām adhi bhāgadheyam ... (Āpastamba Śrautasūtra 4.5.3.)

${ }^{102}$ Thieme, p. 61: "Ihr Schmuck und das Butterschmalz, mit dem sie ihr Antlitz gesalbt hat und das durch die auch von vorn sie bedeckenden Haare hindurchleuchtet, sind die Sterne, die Schleier, in die sie sich kleidet, und ihr schwarzes Haar: das Dunkel."

103 "Piś- signifie en gros «orner, décorer», plus précisément «orner de couleurs vives ou de lumières». Le verbe s'emploie à propos de ciel constellé, en plusieurs passages (l'auteur de X.68, 11 ajoute cette comparaison «comme [on décore] de perles un cheval noir»). D'ailleurs les ténèbres elles-mêmes sont dites pépiśat X.127, 7 «fortement coloriées»... Le Jour et la Nuit sont viśvápeśas, ils ont «toute sorte d'ornements ou de couleurs vives»..." (Renou 1958, pp. 25-6.) Cf. 1.68.10, where Agni is said to have "adorned the firmament with stars" (pipéśa nákam stŕbhir).

${ }^{104}$ Jackson 2001; cf. also West 2007, p. 353. 
unseen to the east across the night sky. ${ }^{105}$ We also meet with the idea that the sun travelled eastwards through the ocean of the nocturnal sky; ${ }^{106}$ whether these are two separate conceptions, or the dark sun and the sun hidden in the waters are different expressions of the same cosmological notion, cannot be discussed here. What is of importance is that the idea of the sun travelling through the night-sky, rather than under the earth, as in other ancient cosmologies, appears to have been the predominant Vedic explanation of the sun's return to the east during night; and that one of the birds being the sun in the nocturnal sky is not an impossible conjecture.

Another possibility is that the crown of the tree on which the birds are perched - this tree being presumably related to the "young woman" in 10.114.3 - is simply the heaven, the diurnal as well as the nocturnal. A cosmic tree, thought to support the firmament, would likely be associated with both. The root piś-, again, is applied to both Night and her sister Dawn, who may here be taken to represent the nocturnal and the diurnal sky; ${ }^{107}$ in 6.49 .3 , for instance, the one is said to have adorned herself with stars, the other "from the sun" (stribhir anyà pipiśé súrro anyấ). Cf. 2.3.6; 10.110.6. The tree, then, may represent both aspects of the sky; and Thieme's ${ }^{108}$ conjecture, that the birds perched on the young woman should be thought of as "niedergesetzt, sicherlich auf jeder Schulter einer, jedenfalls so, daß man jeweils nur einen sieht", may, though made with the waxing and waning moon in mind, be equally well applied to the sun and the moon.

Thieme thought that the two birds become one in 10.114.4-5, proving that they are, in fact, only two different aspects of the moon. This interpretation may be borne out by the initial words of st. 4, ékah suparnáh sá samudrám á viveśa, where it would be better to take ékah suparnáh as "the one, the only bird" than as "one bird" (out of the two). (Cf. Thieme's translation: "Einer ist der Adler." 109 ) St. 5 certainly lends support to the assumption that the two birds are actually one: "The bird, being one (ékam sántam), the priests, the seers, arrange with words in many ways; making verses at the

\footnotetext{
105 Speyer 1906; Sieg 1923; Klaus 1986, pp. 132-42.

${ }^{106}$ Lüders 1951, chap. VIII: "Die Sonne im Wasser".

${ }^{107}$ Cf. Renou 1958, p. 26.

${ }^{108}$ Thieme, op. cit., p. 61.

109 Op. cit., p. 62.
} 
sacrifices, they measure out the twelve cups of soma." The stanza is in fact loosely derived from the famous "monistic" stanza 1.164.46: "They call him Indra, Mitra, Varuna, Agni, and he is the heavenly feathered bird. What is one, the priests speak of in many ways: they call it Agni, Yama, Mātariśvan."110

The bird in 10.114.4 could plausibly enough be taken as the moon; but the sun is equally possible: "The one bird has entered the ocean; he surveys this entire world. With an immature mind, I watched him close by. The mother licks him, and he licks the mother." Thieme took the last, cryptic sentence to mean that the moon is licked by its "mother", Night, whereby it diminishes; licking its mother, however, it becomes replenished (by the light of the heaven). Geldner saw here Agni and his "mother", the fire-stick; Haug, lightning and the earth (its "mother" because clouds arise from the terrestrial waters sucked up by the sun). ${ }^{111}$ Prominent especially in Thieme's interpretation is the notion that the "licking" (rih-) must result in a diminishing of the thing licked, as if it were consumed. This poetic figure (based on the common sight of cows licking their calves) is, however, common in the RV, e.g. in connection with Soma, whose "mothers" (pl.) are the waters in which the soma-stalks are laid down (and, correspondingly, the waters of heaven surrounding the divine Soma). For my part, I suspect that what is meant in 10.114.4 is either the sun or the moon, "licking" the heaven (the word dyaús-, if implied, being feminine) with its rays while at the same time being licked, i.e. touched, by the sky; or moistened by the waters of heaven, which are mentioned in the verse. ${ }^{112}$

\footnotetext{
${ }^{110}$ indram mitrám várunam agním āhur átho divyáh sá suparnó garútmān / ékam sád víprā bahudhă vadanty agnịm yamám mātarísvānam āhuh //.

${ }^{111}$ Haug, op. cit., p. 482.

112 Though the personified Dyaús is male, his "womb" is sometimes referred to. Cf. 5.47.3, which shows some similarities with 1.114 .4 (e.g., suparnáh ... á viveśa): "The ox, the ocean (samudró), the ruddy bird, has entered the ancient Father's (= Heaven) womb. A speckled stone (= the sun), laid down in the middle of the sky, he strides out; he guards the ends of space." (ukșá samudró arusáh suparnáh púrvasya yónim pitúr á viveśa / mádhye divó níhitah príśnir áśmā ví cakrame rájasas pāty ántau //.) The heaven is the "womb" from which the sun (here possibly identified with Soma, who typically carries the epithet samudrá-; cf. Hillebrandt 1999 II, p. 214) is born every morning (from the heavenly waters; cf. Lüders 1951, pp. 294-307), and which it again enters upon sunset. Agni is said to have been born "from the Asura's belly" (ásurasya jațárād ájāyata, 3.29.14d), while in the first half of the same verse, mention is made of "the mother's lap" in which he shone forth "at the udder" (arocata
} 
"The one bird has entered the ocean" might refer to the sun as well as the moon. Most commonly located in the samudrá- is, however, the sun. ${ }^{113}$ As a bird hidden in the ocean (of the nocturnal sky), it is referred to as a great mystery in 10.177.1: "The bird, anointed with the magic of the Asura, the inspired ones see with their hearts, with their mind. The seers behold him within the ocean; the wise ones seek the footprint of the rays". ${ }^{114}$ But the moon can also, as we have seen, be called a suparná- in the waters (apsú); and it is sometimes found in the heavenly waters. ${ }^{115}$ The statement that the bird, having entered the ocean, "surveys this entire world" (idám viśvam bhúvanam ví caște), would however seem to point to the sun, which, as seen, is not only frequently referred to as watching the world or all beings, but is often called a bird when doing so. It is possible, then, that the verses 10.114.4-5, while "mystically" identifying the two birds in st. 3, still describe them separately as two different aspects of the "one bird": this bird being both the sun (st. 4) and the moon (5).

\section{Soma and the world-tree}

We have suggested an identification of the "eating" bird of 1.164.20 with the moon apportioning the "share of the gods" in 10.85.19, and one of the two birds perched "where the gods receive their share" in 10.114.3. Of course, eating and portioning out are not the same thing, although both acts, in these cases, appear to be connected with the soma or the amrta- of the gods. 1.164.21-22, however, suggest a

mātúr upásthe yád áśocad údhani). Lüders (1959, p. 390) recognizes that "der Asura wird Dyaus sein", and that Agni must here be the heavenly fire, though he is less certain as to what to do with the "mother": "Die Mutter, in deren Schoß Agni weilt, wird wohl für die „Mütter" stehen, in deren Schoß der himmlische [Agni] öfter erscheint". (Brackets by Alsdorf.) Another possibility is that we are here faced with an androgynous Dyaus. Cf. also 10.124, where the "Father Asura" inside whom Agni has been dwelling (antár asminn, st. 4) is usually identified as Dyaus.

${ }^{113}$ Cf. Lüders 1951, p. 300, who likewise sees the bird here as the sun: "Für die Sonne ist also der Aufenthalt in dem Meere ebenso charakteristisch wie das Überschauen der Welt."

114 patamgám aktám ásurasya māyáyā hrdà paśyanti mánasā vipaścítah / samudré antáh kaváyo ví cakṣate márīcīnām padám ichanti vedhásah //.

${ }^{115}$ See the passages from RV and AV in Kirfel, op. cit., p. 31 (who, however, wrongly takes Soma in the RV to be the moon). 
similar notion of a distribution of divine nourishment, mentioning a plurality of "honey-eating" birds who cry out for a "share of amrita-". (An image inspired by the sight of parent birds feeding their young? $\left.{ }^{116}\right)$ If one of the two birds can be identified as the moon, its "eating" would refer to the moon's waxing. Thieme, as we have seen, thought that what is "eaten" by the moon must be the light of heaven, which may be designated as amrta-. Middle Vedic texts, though, often state that the moon, "king Soma", is the food of the gods (e.g., ŚB 1.6.4.5, 11.2.5.3: somo rājā devānām annam yac candramāh), consumed by them during the fortnight of the waning moon. We find the theory already developed in RV 10.85.5: "When they drink you up, o god, then you swell again. Vāyu is the guardian of Soma; the moon ( $m \dot{a} s a)$ is the form of the years." ${ }^{" 117}$ One Middle Vedic theory holds that the soma, during the moon's waning, enters the plants and waters and, after these have been consumed by cattle, the milk of cows; this is then used up by brahmins in the sacrifice, which causes the moon to wax again. ${ }^{118}$ The waxing of the moon is rarely described in terms of its "eating"; ${ }^{119}$ rather, the moon itself is consumed and made to wane. It is, however, conceivable that the bird's eating the "fig" in 1.164.20 is a poet's way of referring to the moon's swelling. The plural birds feeding on the same figs in 21-2 may then be the cause of its waning; this would correspond to the gods' receiving their "share" in 10.85.19 and 10.114.3, and their consuming king Soma in Middle Vedic texts. ${ }^{120}$

\footnotetext{
${ }^{116}$ Thieme (p. 61 n. 2) brings (cautiously) up the possibility of the two birds in 10.114.3 actually being a couple - a male and a female; the masculine dual in suparnáa and the meaning "male" of vŕssanā being cases of elliptic dual (cf. Delbrück 2009 [1888], p. 98). Nothing seems, however, to speak for this suggestion; the two birds in 1.164 .20 are both male (cf. anyáh ... anyó). The explicit statement that the birds are male (vŕșanā) may be a way of telling us, using the riddle-like style of the poets, that their unspoken names are masculine; all the Vedic names for the sun and the moon are masculine.

${ }_{117}$ yát tvā deva prapíbanti táta á pyāyase púnah / vāyúh sómasya rakșitá sámānām má̀sa á ákrtih $/ /$.

${ }^{118}$ This theory is often stated in connection with the sāmnāyya rite, an offering of milk to Indra. Cf. Wilden, op. cit., pp. 79-94.

${ }^{119}$ Cf. the late text ŚB 1.6.3.17 (where the swelling Moon/Soma, who is here identified with the slain demon Vrtra, is called a "food-eater", annāda-).

${ }^{120}$ Mention should be made of another passage - 5.54.12a-b - featuring figs (pippala), which have been interpreted as soma: "You shake, o Maruts, the shining fig from the firmament, whose splendor is ungraspable to the outsider." (tám nắkam aryó
} 
Much has been written about the ancient Indian conception of a cosmic tree, and the connection of this tree to the drink of immortality. ${ }^{121}$ The Vedic world-tree is usually an aśvattha, though in some of the earliest mentions it is not specified what kind of species it belongs to. It is probably the cosmic or celestial tree that is referred to in RV 10.135.1a-b as "the tree of beautiful foliage, under (or 'in'?) which Yama drinks in company with the gods", ${ }^{122}$ and in the muchdiscussed 1.24.7:

In the bottomless space, king Varuna, of purified intellect, holds the tip of the tree upwards. [The branches] stand downwards, the bottom above; may their rays be laid down in us. ${ }^{123}$

This inverted tree recurs in several younger texts, where it is specified that it is an aśvattha. In Kaṭa Upanișad 6.1, ${ }^{124}$ we are given a famous description of this tree, which is here identified with the cosmos:

This eternal aśvattha-tree has its roots above and its branches downwards. It is the semen, it is brahman, it alone is called amrta. All the worlds rest on it; no one passes beyond it. ${ }^{125}$

In Taittirīya Āranyaka 1.11 .5 , we are merely told that the one who knows the "tree with its roots above and its branches downwards" (ürdhvamūlam avākśäkham vrkșam) overcomes death. The inverted tree as a representation of the cosmos recurs, more or less reduced to an allegory, in MU 6.4 and Bhagavadgītā 15.1ff.

ágrbhītaśocișam rúśat píppalam maruto ví dhūnutha.) Cf. Viennot 1954, p. 27; Oberlies 2012, p. 433 n. 164, who both make the comparison with 1.164.20-22. The reference would be to the soma descending from heaven with the rain sent by the Maruts.

${ }^{121}$ Valuable studies of the Vedic "world-tree" or "tree of life" (as it is variously called) include Kirfel 1967 [1920], p. 7; Thieme 1949; Viennot 1954, p. 25ff, 74ff; Bosch 1990 [1964]; Kuiper 1983, pp. 76ff, 123ff, 143ff; Emeneau 1988; Lommel 1978, pp. 389-400, 512-23; Falk 1994. Cf. now also Oberlies 1998, Index, s.v. "Weltenbaum", and Parpola 2015, pp. 201-207, 278ff, 310-11.

122 yásmin vorkșé supalāsé devaịh sampíbate yamáh.

123 abudhné rájjā váruno vánasyordhvám stūpam dadate pūtádakṣah / nīcìnā sthur upári budhná eșām asmé antár níhitāh ketávah syuh //.

${ }^{124}$ I have used Olivelle's (1998) edition for all Upanișads, except for the Maitrī and Mahānārāyaṇa Upaniṣads, for which van Buitenen's (1962) and Varenne's (1960) editions have been employed.

${ }^{125}$ ürdhvamūlo 'vākśäkha eșo 'śvatthah sanātanah / tad eva śukram tad brahma tad evāmrtam ucyate / tasmim̄l lokāh śritāh sarve tad u nātyeti kaścana //. 
Early scholars suggested that the image of the inverted aśvattha must have been the result of a conflation with the nyagrodha-tree, with its downward-hanging aerial roots. ${ }^{126}$ Emeneau, while pointing out the absurdity of the idea that Indians would confuse the two trees, still held that the inverted tree of unspecified species in RV 1.24.7 must have been a nyagrodha, and that a stereotyped image of an upsidedown tree eventually was transposed to the more sacred aśvattha. ${ }^{127}$ At the same time he noted that an inverted tree is a widespread motif that appears in cosmologies and myths throughout Eurasia. ${ }^{128}$ This latter fact, well-known from ethnology, made Kuiper conclude - rightly, I think - that "[t]he idea that a nyagrodha could have been meant ... is no longer discussible". ${ }^{129}$ The tree, then, has no naturalistic basis, its invertedness having a purely mythico-cosmological meaning.

An aśvattha, growing in the Himalayas, is also mentioned in a passage occurring in AV 5.4.3, 6.95.1, and 19.39.6 (AVP 7.10.6, 19.11.1, 20.51.8); it is part of a charm dealing with the healing kușthaplant:

The asvattha-tree is the seat of the gods in the third heaven from here. There the gods procured the kushtha, the visible manifestation of amrita (ambrosia). ${ }^{130}$ (5.4.3, tr. Bloomfield.)

19.39.6 adds: "The all-healing kuștha stands together with soma."131

The healing herb is here identified with the amrta, which, as we have seen, is also found in the crown of the tree in RV 1.164.20-22. The passage is also the first clear example of a transposition of the

\footnotetext{
${ }^{126} \mathrm{Cf}$. the references to Charpentier, Deussen, Garbe, and Otto in Emeneau, op. cit., p. 24. The view that the nyagrodha must be meant in RV 1.24.7 is still to be found in Bosch, op. cit., p. 69 n. 12; cf. now also Parpola, op. cit., pp. 201-204 (who sees the mythical tree here as derived from the culture of the Indus Civilization).

${ }^{127}$ Op. cit., pp. 24-5. On the prominent part played by the aśvattha in Vedic ritual and imagination, see e.g. Krick 1982, Index, s.v. Aśvattha.

${ }^{128}$ It appears in the mythologies of various subarctic peoples, as well as in mediaeval Christian, Jewish, and Islamic traditions, where it has taken on an allegorical meaning similar to the one in the Bhagavadgita (the phenomenal world originating from the divine or celestial sphere, in which it is "rooted"). Studies of the image of the inverted tree include Jacoby 1928; Kagarow 1929; Coomaraswamy 1977; Holmberg 1996, pp. 25, 67; Eliade 1996 [1958], p. 274ff; and, especially, Edsman 1966.

${ }^{129}$ Kuiper 1983, pp. 145-46.

130 aśvatthó devasádanas trotíyasyām itó diví / tátrāmrítasya cákṣanam devăh kúștham avanvata /l.

${ }^{131}$ sá kúștho viśvábheșajạ sākám sómena tișțati.
} 
cosmic tree to heaven, as Thieme noted. The words "in the third heaven from here" (tritìyasyām itó divi) recur in Chāndogya Upanișad 8.5.3, describing Brahman's heaven; in this celestial paradise we find, interestingly, an aśvattha-tree called Somasavana, "Flowing with soma", again suggesting a connection with the drink of immortality. (In the Kaușitaki Upanisad, 1.3, the name of the celestial tree is Ilya, probably from $i l \bar{a}-/ i r \bar{a}-$, "nourishment, refreshment". ${ }^{132}$ ) It should also be pointed out that there is yet another context in which the words tritiyasyam ito divi occur: in the Middle Vedic myth of the theft of the soma from heaven by a bird of prey (suparna-). As Kuiper has remarked, ${ }^{133}$ the various versions of this story often include a stereotyped phrase, "The soma was in the third heaven (from here)", ${ }^{134}$ it is clearly derived from the AV passage quoted above. Though no celestial tree is mentioned in this story, and it never is made clear whether the soma fetched by the bird is the plant or the liquid, it is clear that the "third heaven from here" in the Black Yajurveda has become a stereotyped expression associated with the heaven where the soma or amrta was located. ${ }^{135}$

Elsewhere, mention is made of a tree at the centre of the world, under the name of Plakșa Prāsravana, the "fig-tree at the spring". ${ }^{136}$ It is said to stand at the source of the sacred river Sarasvatīi ${ }^{137}$ here is the world of heaven (svarga-loka-). This world is reached through the särasvatasattra- ${ }^{138}$ a pilgrimage from the place where the Sarasvati disappears in the desert to its source in the Himalayas, at the foot of

\footnotetext{
${ }^{132}$ Cf. Thieme 1949, p. 69 n. 4.

${ }^{133}$ Kuiper 1996, p. $230 \mathrm{ff}$.

134 trotìyasyām vaí diví sóma āsīt: MS 4.4.1; Kāṭhaka Saṃhitā 30.10; Kapișțhala-Kațha Saṃhitā 46; trtí̀yasyām itó diví sóma āsīt: Kāṭhaka Saṃhitā 23.10; Kapișțhala-Kaṭha Saṃhitā 37.1; TS 3.5.7.1; TB 1.1.3.10, 3.2.1.1.

${ }^{135}$ Kuiper himself does not remark on the presence of the ambrosia and soma there already in the AV.

${ }^{136}$ Cf. Macdonell \& Keith 2007 [1912], s.v.; Kirfel, op. cit., p. 7; Thieme, op. cit., p. 70 (“der Feigenbaum an der Quelle [der Sarasvatī]"; Bharadwaj 1978.

${ }^{137}$ The statement, found e.g. in Macdonell \& Keith, op. cit., that some sources (notably PB 25.10.16, for which see a later note) locate the tree at the place where the Sarasvatî disappears in the desert, has been shown by Bharadwaja (esp. p. 480ff) to be based on a misunderstanding.

${ }^{138}$ See also Krick, op. cit., pp. 496-99. The pilgrimage along the Sarasvatī to the entrance of heaven recurs as a motif in parts of the Mahābhārata: Austin 2008.
} 
the fig-tree. ${ }^{139}$ As Witzel ${ }^{140}$ has demonstrated, the celestial Sarasvati the Milky Way, seen as the heavenly counterpart of the terrestrial river - is meant. The explicit statement that the tree stands in the middle of the world makes it the clearest Vedic example of the conception of an axis mundi. The notion that it stands at the source of the Sarasvati further seems to connect it with the celestial tree Somasavana or Ilya, which is said to stand near some body of water - the "pond Airammadiya"141 and two "oceans" in the Chāndogya passage, or the "river Vijarā" and the "lake Āra" in the Kauṣitaki (1.3). These are probably Upanișadic incarnations of the heavenly waters of the Vedic hymns. ${ }^{142}$ In epic and other post-Vedic sources, we find the notion of a gigantic banyan tree (nyagrodha-) standing in the ocean; ${ }^{143}$ the imposing banyan would here seem to have replaced the aśvattha.

139 "At a distance of a journey of forty[-four] days on horseback from the spot where the Sarasvatî is lost (in the sands of the desert), (is situated) Plakṣa prāsravanana. At the same distance from here (from the earth) (is situated) the world of heaven; they go to the world of heaven by a journey commensurate with the Sarasvatî." (PB 25.10.16, tr. Caland; my brackets. catuścatvārimśad āśvīnāni sarasvatyā vinaśanāt plakṣah prāsravaṇas tāvad itạh svargo lokah sarasvatīsammitenādhvanā svargam lokam yanti.) In JB 2.298 (not cited by Macdonell \& Keith; cf. Caland 1970 [1919], p. 201f, for a translation), we learn: "They walk along the Sarasvatī. Sarasvatī is Speech. The god-travelled path is Speech; they walk there along just the god-travelled path ... They walk rising up to just that heavenly world. They walk from the Prakșa Prāsravaṇa. This Prakṣa Prāsravana is the end of Speech; where the end of Speech is, there is the heavenly world. They go here to just that heavenly world." (My tr.; sarasvatyā yanti. vāg vai sarasvatī, vāg u devayānah panthā. devayānenaiva tat pathā yanti ... svargam eva tal lokam rohanto yanty, a prakșāt prāsravanād yanty; eșa u ha vai vāco 'nto yat prakșah prāsravaño; yatra ha vai vāco 'ntas tat svargo lokaḥ. svargam evaital lokam gacchanti.) In $J U B 4.26 .12$ (quoted below), the tree is said to stand in the centre of the earth and the sky.

${ }^{140}$ Witzel 1984

141 "Für: *airāmadīya ,Nahrung (irā) und Rauschtrank (mada) (d. h. Milch und Soma) enthaltend?" (Thieme, p. 69 n. 1.)

${ }^{142}$ Thieme (p. 69) further compares these trees to the pārijāta-, a flower-bearing celestial tree that grows in Indra's heaven, according to classical Sanskrit literature. The name, he suggests, is a prākrnt word derived from an original *pārejāta-, "growing (lit. 'born') on the shore". In Kālidāsa's Raghuvaṃśa, 10.11, Viṣnu, resting on the primeval waters, is said to appear "like another Pārijāta in the midst of the waters" (apāṃ madhye pārijātam ivāparam). (The likeness is due to his (four) bangled arms, which are said to be reminiscent of tree-branches.) The image, then, is one of a celestial tree standing surrounded by water.

${ }^{143}$ In the Mārkandeya episode in the Mbh (3.180-221), the sage Mārkandeya, drifting about on the surface of the water after the deluge, comes across an enormous banyan (nyagrodham sumahāntạ̣ vai viśālam, 186.81; cf. 186.114) in whose branches a 
Comparatively little attention has been paid to the - certainly late passage Mbh 5.45.9, a part of the Upanișadic-style Sanatsujātīya. ${ }^{144}$ If read together with the two preceding stanzas (7-8), it may, however, shed some important light on the ancient Indian conception of the world-tree.

The powerful ones then travel along the twelvefold stream, the terrible honey guarded by the gods.

[Refrain:] The yogins behold the eternal Lord.

Having collected it, the bee drinks the half-monthly honey. The Lord arranged it as an oblation among all beings. The yogins etc.

Wingless ones have rushed toward the golden-leafed aśvattha; having there become birds, they fly out in their respective directions. The yogins etc. ${ }^{145}$

The "honey" (madhu), which is said to be twelvefold (dvädaśapūgā-) and "half-monthly" (ardhamāsa-), would be the soma (the "oblation"), being consumed in the fortnight of the waning moon. The bee's collecting and then drinking the honey would seem to refer to the waxing and waning of the moon, respectively, in which case the image of the moon as a collection or receptacle of soma is implied; or the bee itself may be the moon, and the drinking what causes it to swell for a half month, like the fig-eating bird in Thieme's interpretation. That the golden-leafed aśvattha is no ordinary tree, but related to the aśvattha in Katha Upanișad and other texts, need hardly be said. The birds are reminiscent of those in RV 1.164.21-2, which

divine child (the creator, Nārāyaṇa) is reposing. In a somewhat similar episode in the Kathāsaritsāgara (26.3), a fishing ship happens to come upon the "divine banyan-tree" (devo vatadrumah), rising like a mountain in the midst of the sea; under it is a vast maelstrom (sumahāvartam) which drags the ship down to the submarine fire (vadavāmukham). (9-10.) The maelstrom may conceivably represent the centre of the ocean.

${ }^{144}$ Cf. van Buitenen 1978 for a complete translation.

${ }_{145}$ dvādaśapūgām saritam devarakșitam / madhu ìsantas tadā samcaranti ghoram / yoginas tạn prapaśyanti bhagavantam sanātanam //

tad ardhamāsam pibati samcitya bhramaro madhu / ìsānah sarvabhūteșu havirbhūtam akalpayat / yoginas tạ̣ prapaśyanti bhagavantạ sanātanam //

hiranyaparnam aśvattham abhipatya apakșakāh / te tatra pakșino bhütvā prapatanti yathādiśam / ... 
seek the amrta; their getting wings and flying away presumably mean that they attain immortality, or liberation. ${ }^{146}$

The world-tree, then, is a fig-tree (aśvattha, plakșa), standing in the centre of the world, or sometimes in heaven; and closely associated with the heavenly waters and the drink of immortality. Sometimes it is said to stand in an inverted position, an image taken up by a later tradition and turned into an allegory of the world. But what may have been the original meaning of this conception? Kuiper put forward an ingenious theory that sought to explain the inverted tree in the light of early Vedic cosmology. ${ }^{147}$ Attaching special significance to the fact that Varuna, the god of the nocturnal sky and the waters (not least the heavenly waters), is in RV 1.24.7 said to hold the inverted tree from above, he went on to compare this passage to 5.85.3:

Varuna has poured out the jar, its brim turned downwards, over heaven and earth and the atmosphere. The king of the whole universe moistens the earth with it, like rain (moistens) barley. ${ }^{148}$

The "jar" (kávandha-) is clearly used by the god for pouring out the heavenly waters over the earth, in the form of fructifying rain or, as seems to be the case here, dew. ${ }^{149}$ This heavenly jar or pail is, however, not unique to this particular passage; in fact, it figures rather often in the RV and the AV, and is handled by a number of different gods, most often the Maruts or storm-gods, who are closely associated with rainfall. ${ }^{150}$ They use the "jar" (for which the word kóśa- is most often used) to draw (áa cyāvaya-) water from the heavenly ocean, then

\footnotetext{
${ }^{146}$ Like the post-Vedic descriptions of the inverted tree, these passages probably reflect younger ideological trends. The honey being "terrible" (ghora-) may point to the notion that even the gods are stuck in metempsychosis, and that the prolonged life gained from soma or amrta- is not true immortality. If the tree, as in Bhagavadgitan etc., represents the (physical) world, then the birds' getting wings and leaving the tree would seem to be an image for final liberation from the chain of rebirths.

${ }^{147}$ Kuiper 1983, chap. 6: "The Heavenly Bucket".

148 nīcínabāram várunạ̣ kávandham prá sasarja ródasī antárikṣam / téna viśvasya bhúvanasya rájjā yávam ná vrșțír vy ùnatti bhúma //.

${ }^{149}$ If rainfall were the object of the passage, the words "like rain" (ná vrstitir) would make a rather clumsy comparison (rain falling on the earth being likened to rain that falls on barley). If Kuiper's inference is right, the setting would further be the nocturnal sky; making it likely that the reference is to dew falling on earth during the night.

${ }^{150}$ Kuiper, op. cit., p. $147 \mathrm{ff}$.
} 
they tilt it so that the water is poured out as rain. Probably it is the same jar that is referred to in the mahāvrata festival, where young women, in what appears to be a rain-making ritual, walk around the mārjälìya fire with water-filled pitchers (kumbha-) on their heads, chanting, "This is honey!" (idam madhu); the head representing the sky according to JB 2.404. ${ }^{151}$ Lüders ${ }^{152}$ recognized that this jar must be identical with what is elsewhere in the RV referred to as the "spring" (útsa-), "well" (avatá-), or "udder"153 (立dhan-) ${ }^{154}$ of the sky, from which flow streams of "honey" (mádhu). That this spring is the source of rainfall can be inferred from passages such as: "They who, like drops, blow over heaven and earth with the rains, milking the inexhaustible spring" ${ }^{155}$ (8.7.16); “... the Maruts, bearing pails, cause the spring to swell, as the mighty ones roared; they moisten the earth with the sap of the honey" 156 (5.54.8); "They milk the thundering, inexhaustible spring" 157 (1.64.6); "They who pour out the inexhaustible spring, who constantly sprinkle the sap into the plants" ${ }^{\prime 158}$ (AV 4.27.2), etc. ${ }^{159}$ That the contents of the jar or spring are

151 etad vai pratyakșam divo rūpam yan mūrdhā; pointed out by Witzel 1996, p. 535 and n. 19. Cf. transl. by Caland 1970 [1919], pp. 215-16. For the ritual, see e.g. Rolland 1972, esp. p. 18ff; Thite 1975, pp. 100-103.

${ }^{152}$ Lüders 1959 , pp. 375-95. His conclusions were largely accepted by Kuiper, op. cit., p. 141ff, who however argued that the jar or spring actually belongs to the netherworld, being situated above the earth only at night. On the heavenly spring cf. now also Oberlies 2012, Index, s.v. Soma-Born.

${ }^{153}$ Like an udder, the spring is said to have four apertures from which its contents flow (AV 18.4.30a-b: "They milk the vessel, the jar with four openings, this honeyrich cow, for well-being”, kóśam duhanti kaláśam cáturbilam ị̂ạm dhenúm mádhumatīn svastáye). As Lüders (1951, p. 285; cf. 1959, p. 381) noted, its four streams are the precursors of the four rivers flowing down the slopes of the worldmountain Meru in post-Vedic cosmology. Kuiper (1983, p. 142) suggested, as we have seen, that this image is implied in the young woman with four plaits in RV 10.114.3.

${ }^{154}$ In fact, some adjectives used to designate this spring or receptacle (which is frequently said to be "milked" by the gods) occur elsewhere as ways of referring to the udder of a cow: cf. the "udder with four apertures" (í dhaś cáturbilam) in RVKh 4.12.1, and the "cow with opening(s) downwards" (gávi nīcínabāre) in RV 10.106.10. In both cases, ordinary cows are described.

${ }_{155}^{155}$ yé drapsá̀ iva ródasi dhámanty ánu vrștíbhih / útsam duhánto ákșitam //.

156 ... marútah kabandhinah / pínvanty útsam yád inắso ásvaran vy ùndanti prothivím mádhvo ándhasā //.

${ }^{157}$ útsam duhanti stanáyantam ákșitam.

${ }^{158}$ útsam ákșitam vyácanti yé sádā yá āsiñcánti rásam óṣadhiṣu.

${ }^{159}$ I refer to Lüders 1959 , p. $385 \mathrm{ff}$. 
frequently referred to as "honey" does not speak against this, as water, especially the heavenly waters (divyá apáh), is often said to be or to contain honey, ghee, milk, amrta-, or soma. The notion underlying such descriptions is that a heavenly sap or essence (rása-), on which the gods feed and which is concentrated in the soma and other libations, is contained in water, reaching earth through rainfall and entering into plants and the milk of cows. ${ }^{160}$

Back to the jar with its bottomside up. Kuiper notes that the two passages 1.24.7 and 5.85.3 both treat a situation wherein something is

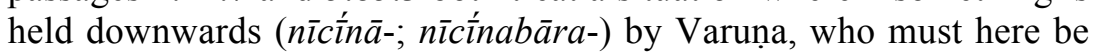
envisaged as residing in the night-sky. Seeking to reconcile the god's seemingly conflicting functions as ruler of both the nocturnal sky (containing the heavenly waters) and the underworld (with the subterranean waters), he posits a conception of a nightly inversion of heaven and underworld, whereby the cosmic tree, connecting heaven and earth (and underworld), is turned upside-down so that its roots, and Varuna's underworld, temporarily appear above the earth. The vessel, standing in Varuna's dwelling at the root of the tree, is then turned downwards, and its contents are emptied out over the earth.

Kuiper's theory has not met with unanimous acceptance. ${ }^{161}$ Certainly the cosmological image it describes is fantastic, and its reconstruction rests heavily upon two passages occurring in different hymns. It has, however, received some support from Bodewitz, ${ }^{162}$ who, while skeptical to parts of Kuiper's theory, has shown that the waters of heaven and those under the earth are often interchangeable in the cosmological classifications of Middle Vedic texts, suggesting that they are, in fact, identical.

\footnotetext{
${ }^{160}$ See Rönnow 1927, chap. 2: "Das Lebenswasser"; cf. Lüders, op. cit., p. $351 \mathrm{ff}$.

${ }^{161}$ Klaus (1986), whose study however deals with younger (Middle Vedic) materials, states (p. 69): "KUIPERs Ansichten lassen sich nach unseren Quellen nicht belegen. Von dem kosmischen Baum wissen diese nichts." According to Oberlies (2012, p. 421 n. 56), the theory "hat in den Texten keinerlei Stütze, von der bloßen Wahrscheinlichkeit der Existenz einer solchen Konzeption einmal ganz abgesehen". Wilden (2000), though generally critical of Kuiper's approach to the texts, does not treat the rain-jar in her monograph on Vedic rain-theories.

162 Bodewitz 1982, 2000.
} 


\section{The heavenly soma-vessel and the stars of Ursa Maior}

A connection between the nocturnal sky and the rain-vessel has, however, been definitely established by Kuiper's disciple, Witzel, ${ }^{163}$ who has brought the previously neglected passage AV 10.8.9 into the discussion of the heavenly vessel. ${ }^{164}$ It may be translated as follows:

The bowl (camasá) has its opening sideways and its bottom above. In it, dazzling glory is deposited.

There sit together seven seers, who have become the guardians of the great one. ${ }^{165}$

The Bṛhadāraṇyaka Upaniṣad, 2.2.3, has a partly different version:

The bowl has its opening downwards and its bottom above. In it, dazzling glory is deposited. On its rim sit seven seers, with Speech, united with brahman, as the eighth. ${ }^{166}$

The Upanișad goes on to comment upon this stanza, claiming that the overturned bowl is the human body, in which reside seven vital forces (prānas). ${ }^{167}$ At the same time, however, it gives us the proper names of the seven seers sitting on the bowl: they are Gotama, Bharadvāja, Viśvāmitra, Jamadagni, Vasișțha, Kaśyapa, and Atri. (2.2.4.) These are among the most common names assigned to the mythical "seven seers" (saptarsayah), although they vary. Now, the "Seven Seers" is the name of the constellation Ursa Maior (the Great Wain, the Big Dipper) with its seven stars. ${ }^{168}$ Witzel makes the following observations on the shape and movements of this constellation:

\footnotetext{
${ }^{163}$ Witzel 1996.

${ }^{164}$ The significance of this passage for Vedic cosmography and starlore had been pointed out by Brereton (1991) in a lengthy discussion.

${ }_{165}$ tiryágbilaś camasá ùrdhvábudhnas tásmin yáśo níhitam viśvárūpam / tád āsata ř́sayah saptá sākám yé asyá gopá maható babhūvưh //.

${ }_{166}$ arvāgbilaś camasa ūrdhvabudhnas tasmin yaśo nihitạ̣ viśvarūpam / tasyāsata rșayah sapta tīre vāg așțamī brahmaṇā samvidāneti \%.

${ }^{167}$ The localization of the seven seers in the human body is actually not entirely fortuitous, but is found in some other texts: cf. Ehlers 2007 (who posits a parallelism between the body and the stars of Ursa Maior).

${ }^{168}$ On this constellation and its designations in ancient India, cf. Mitchiner 2000 [1982]; Witzel 1999; Scherer 1953, pp. 131-41. Cf. now also Parpola 2015, pp. 19698, 209, 311 (who, of course, posits an Indus Civilization origin).
} 
If one actually observes the movement of Ursa Maior one can easily see that this asterism actually turns upside down every night. [...] Observation [...] shows that the Great Wain/Wagon/Bear/Ursa Maior has the form of a big ladle that is emptied out every night: it slowly turns around, scooping up the heavenly water and then releasing it over the earth lying beneath it. ${ }^{169}$

He further notes that this asterism has been called or likened to a water-containing vessel in many cultures. ${ }^{170}$

These observations certainly support Kuiper's theory of a connection between the rain-vessel and the nocturnal sky. They also explain why the opening of the vessel is said to be sideways instead of downwards in the AV passage: this is well in keeping with the movements of Ursa Maior. ${ }^{171}$ But there is more, I think, that can be gleaned from this localization of the vessel. The Seven Seers are mentioned in connection with the cosmic tree, Plakṣa Prāsravana, in JUB 4.26.12:

Just one span to the north of the Plakșa Prāsravana is the middle of the earth. And where these Seven Seers are, there is the middle of the sky. (Tr. Oertel, slightly modified.) ${ }^{172}$

Thieme ${ }^{173}$ translates the last part, "Und wo diese 'Sieben Seher' (Ursa major) sich befinden, [um das Maß einer Spanne nördlich davon] da ist die Mitte des Himmels"; justifying, in a footnote, the brackets with the remark that "ja nicht Ursa major sondern der Polarstern (Ursa minor $\alpha$ ) die Mitte des Himmels bezeichnet". It is true that the constellation is situated somewhat to the north of the northern celestial pole, and that the Seven Seers are usually said to be "in the north" in Vedic texts. ${ }^{174}$ Any polestar proper did, however, probably not exist at the time of the composition of this text (before the middle of the $1^{\text {st }}$

\footnotetext{
${ }^{169}$ Witzel 1996 , p. 540 . Cf. the plates on p. 544, showing the movements of the constellation as they would have appeared over Panjab around 1800 B.C.E.

${ }_{170}$ Op. cit., pp. 541-42.

${ }^{171}$ Op. cit., p. 537 n. 23.

172 plakșasya prāsravanasya prādeśamātrād udak tat prthivyai madhyam. atha yatraite sapta rșayas tad divo madhyam. Witzel (1984, p. 224) points out that the tree is located at the divo madhyam also in the unpublished Vādhūla Pitṛmedhasūtra.

${ }^{173}$ Thieme 1949, p. 70.

${ }^{174}$ Cf. Mitchiner, op. cit., p. $107 \mathrm{ff}$.
} 
millennium B.C.E.). ${ }^{175}$ The present polestar, Polaris or $\alpha$ Ursae Minoris, did not reach this position until after the $6^{\text {th }}$ century B.C.E.; in ancient India, the polestar (dhruva-, the "fixed one") is first mentioned in late Vedic texts ( $\mathrm{T} \overline{\mathrm{A}}$, Gṛhyasūtras) which can be dated to the last few centuries B.C.E. ${ }^{176}$ It is very possible, then, that the passage quoted lets the Seven Seers represent the centre of the sky, in the absence of a polestar proper. This is the solution suggested by Mitchiner: "Since the constellation of the Seven Rșis or Ursa Major is that closest to the centre-point or 'pivot' of the sky, the above passage may be seen as a poetic - if astronomically slightly imprecise - way of expressing their location." 177 In conclusion, it appears that the constellation was associated with the cosmic tree and the centre of the world; as the tree is said to stand in the middle of the earth, we must think of the Seven Seers as situated above it, or in it. In the custody of these seers is the heavenly jar which, according to Kuiper, stands in the tree and is overturned each night.

I would like to draw some attention to the mantra TS 4.2.9.1 (= MNU 370-71), which has so far been neglected in scholarly

\footnotetext{
${ }^{175}$ The problem of the polestar in ancient Indian literature has been treated in detail by Liebert 1968/1969.

${ }^{176}$ Liebert's high date for the Gṛhyasūtras (800-600 B.C.E.) makes him identify the star Kochab ( $\beta$ Ursae Minoris), which was close to the pole at this time, as the "polestar" of the texts. He also thinks that the dhruvadarśana-rite of the Grihyasūtras, in which a newly-wedded bride is made to point towards the polestar, "originally" concerned Thuban ( $\alpha$ Draconis), which was located at the pole in the early third millennium B.C.E.; and that the ritual originated among the indigenous populations of India, to be taken up by the Indo-Aryans only at a late date. Liebert has recently been followed by Parpola (2015, pp. 200-201), who holds that the origins of the rite must date "from the time of the Indus civilization". I do not see any reasons for these conjectures. As the earliest Grihyasūtras are today dated to the last few centuries B.C.E., the polestar referred to is most likely to have been Polaris; and the dhruvadarśana- may well have originated only at this time (after Polaris had become the polestar), making it unnecessary to assume some pre-Aryan ritual that had survived throughout the millennia to resurface in the literature at this late date.

${ }^{177}$ Op .cit., p. 108. He adds: “... the constellation of the Seven Rșis would at this earlier period have been not only perhaps the most easily recognisable constellation in the northern hemisphere, but also unquestionably that closest to what was then the northern celestial pole." Something similar may be the case in RV 10.82.2, where the blessed departed are said to revel "beyond the Seven Seers" (yátrā saptarșín pará); this would seem to designate the highest point of heaven.
} 
treatments of the Seven Seers ${ }^{178}$ - understandably enough, as the "seers" are not here referred to as such. There can, however, hardly be any doubt as to who are meant. I give the following translation:

The inspired thoughts flow together like streams, becoming purified inside through heart and mind. I look at the streams of ghee. In their midst there is a golden reed.

On it sits a honey-making bird (suparná-), nesting, apportioning honey to the deities. On its (the reed's?) rim sit seven yellow ones, milking forth by their own force the stream of amrta- ${ }^{179}$

The first verse corresponds to RV 4.58.6a-b and 5c-d, although these two half-verses have switched place here. Their meaning in the Rgvedic hymn seems to be wholly ritualistic, dealing with the libations poured into the sacrificial fire (which is perhaps the "golden reed"); as is often the case in these hymns, the inspired thoughts of the poet are at the same time "purified" in his heart, like the soma-juice poured through the strainer. In the Yajurvedic mantra, the context seems to be different; the half-verse preceding RV 4.58.6a-b has been placed after it, presumably so that the bird introduced in the next verse could be placed on the "golden reed".

The seven "yellow ones" sitting on the rim can easily be identified as the Seven Seers; the verse being a variant of the one quoted by the Bṛhadāranyaka Upanișad (2.2.3) as tasyāsata ṛsayah sapta tīre. (AV 10.8.9 has tád āsata ŕșayah saptá.) They are said to be "milking forth" the "stream of amrta", being the ones who pour out the contents of the heavenly jar. The golden reed also appears in AV 10.7.41: "He who knows the golden reed standing in the primordial flood (salilá-), he is the hidden Prajāpati." 180 The passage occurs in a hymn that extols Skambha, the "Support", a cosmic pillar holding heaven and earth apart $(10.7 .7,12,35$ etc.); it is sometimes described as a tree with branches (10.7.21, cf. 38). The golden reed in the

\footnotetext{
${ }^{178}$ It is not referred to either by Mitchiner, Witzel, or Brereton. It is however listed by Bloomfield (1906) as a variant of the mantra tasyāsata rșayah sapta tīre (for which see above).

${ }^{179}$ sám it sravanti sarito ná dhénāh / antár hrdà mánasā pūyámānāh / ghrtásya dhấrāa abhí cākaśīmi / hiranyáyo vetasó mádhya āsām // tásmint suparnó madhukŕt kulāyĺ bhájann āste mádhu devátābhyah / tásyāsate hárayah saptá tìre svadhấm dúhānā amŕtasya dhárām $/ /$.

${ }^{180}$ yó vetasám hiranyáyam tișthantam salilé véda / sá vái gúhyah prajápatih //.
} 
Yajurvedic mantra would seem to be the cosmic tree, which, as we have seen, is often said to stand in water, like a reed; as for its being golden, the "golden-leafed aśvattha" of the Sanatsujātīya comes to mind.

Then there is the bird, "apportioning honey to the deities" (bhájann ... mádhu devátābhyah), reminiscent of Soma who as the moon "apportions the share to the gods" (bhägám devébhyo vi dadhaty) in RV 10.85.19; the two birds in 10.114.3, perched "where the gods have received their share" (yátra devấ dadhiré bhāgadhéyam), or the birds in 1.164.21, crying out for the "share" (bhāgám) of the amrta. Of great interest is the word madhukrit, lit. "honey-maker", applied to the bird; this word also has the meaning "bee". We saw that the Sanatsujātīya speaks of a bee (bhramara-) that collects and drinks the twelvefold, half-monthly "honey", i.e. soma. Both the bird and the bee are, I think, reflections of the fig-eating bird in RV 1.164.20. The reason why now only one bird is mentioned may be that the other, watching bird was of no significance to the image of the bird that feeds on and distributes the drink of immortality, perched on the world-tree; in other words, the watching bird became obsolete.

In 1.164.21, the "sweet fig" is said to be at the "top" (ágre) of the (world-)tree (where, by implication, the fig-eating bird sits). This would be the highest point of the sky, which is where the honeyyielding jar or spring is to be found; this agrees well with the fact that Ursa Maior, as we have seen, is situated close enough to the celestial pole to be said to mark the "centre of the sky" in one text. We have also seen that the soma is said to originate in the "third heaven". The ambrosial jar, then, rests at the upper end of the world-axis. ${ }^{181}$

\footnotetext{
${ }^{181}$ But only at night, as Kuiper suggested? According to him, the ambrosial jar stands among the subterranean roots of the tree in the day, to appear in the sky only at night. The image of the figs may speak against such an interpretation in this case, as we would expect them to grow on the branches. The tree in 1.164.20-22 may rather be an example of the celestial tree, standing in the heavenly waters and extending its branches beneath the firmament. It is clear that both images, that of the world-tree rooted in the earth, supporting the sky, and that of the celestial or paradisiacal tree, existed parallel to each other already in Rgvedic, and probably even in Proto-IndoIranian, times (Oberlies 1998, p. 245 n. 472; 2012, pp. 76-7, 81, 190-91, 433 n. 164; and cf. discussion below). The "top" of the celestial tree is probably simply the crown, which would be at the summit of the sky; in its inverted, nocturnal position, this crown may be identical with the night-sky (cf. Thieme), while the roots are above
} 
In view of all these celestial and sidereal associations, it does not seem farfetched to interpret the plurality of birds in RV 1.164.21-2 as the stars (Thieme), perhaps being identical with the Ancestors gone to heaven (Hillebrandt). In favor of this latter view speak the wellestablished beliefs in stars or asterisms as semi-deified ancestors or heroes, in Vedic India as well as among other Indo-European peoples $^{182}$ - the Seven Seers being one example - and the stress on sacred knowledge in the Rgvedic stanzas: no one who "does not know the Father" may reach the sweet fig at the top of the tree. This could hardly refer to the gods. Those who seek to reach, through their knowledge, the top of the tree - the firmament, where the celestial soma is situated - would rather seem to be the priests who desire a celestial existence - perhaps as stars - after death. ${ }^{183}$ This existence is in the heaven of the pious, "where the Ādityas feed on honey on the third firmament" 184 (AV 18.4.3), where Yama drinks in the company of the gods (RV 10.35.1), where god-seeking men inebriate themselves at the "spring of honey" (mádhva útsah) (RV 1.154.5), and the Ancestors venerate the "inexhaustible spring with a thousand streams, with a hundred streams, expanding on the back of the flood"185 (AV 18.4.36).

We mentioned that no actual polestar was in existence in the first half of the first millennium B.C.E., when most of the Middle Vedic literature was composed. In the preceding millennium - at the end of which the Vedic hymns were composed - the star Kochab or $\beta$ Ursae Minoris may have served starwatchers as a sort of polestar, thanks to its brightness and proximity to the northern celestial pole; it was however not as close to the pole as Polaris would later be. Around 1800 B.C.E. it formed, together with two stars in the constellation Draco, a triangle around the pole. ${ }^{186}$ Harry Falk, in a study supportive

it. This could explain the rays or lights (ketávah) said to extend from the downwardreaching branches in 1.24.7: these would refer to the stars.

${ }^{182}$ For India cf. Hillebrandt 1999: I, p. 245; Oldenberg 1894, pp. 564-65; now also Klaus 1986, pp. 156-7 (examples from Middle Vedic texts), Oberlies 1998, p. $471 \mathrm{n}$. 89; 2012, pp. 170-71, 409-10 n. 365.

${ }^{183}$ As we have seen, the birds in the Sanatsujâtīya also appear to be the emancipated souls; though this late text cannot be used as evidence here.

${ }_{184}$ yátrādityá mádhu bhakșáyanti tró̀tye náke.

185 sahásradhāram śatádhāram útsam ákșitam vyacyámānam salilásya prșthé / (... úpāsate pitárah).

${ }^{186}$ Cf. Müller 1970, p. 137 (with a chart). 
of Kuiper's theory of the inverted tree and the nocturnal sky, ${ }^{187}$ has suggested that these three stars are referred to in MU 6.4, which talks about the world-tree as the "three-footed brahman with its root above ... called the One Aśvattha" (ürdhvamūlam tripād brahma ... eko 'śvatthanāmā). Of course, this Upanișad is much later than the period when these three stars circled the pole; but the possibility that it preserves more ancient traditions is increased when one takes into account that a "three-footed" cosmic being is mentioned already in the Vedic hymns. Falk points out that the Purușa or cosmogonic giant of RV 10.90 is said to have risen beyond the earth with "three feet" (tripád ūrdhvá úd ait púruṣah, 10.90.4); this Puruṣa sometimes appears to be assimilated to the world-tree in later texts. ${ }^{188}$ Falk also identifies him with the obscure cosmogonic being Uttānápad who gave birth to the earth according to RV 10.72 .3 and whose name, as Falk shows, means "the one with the soles of the feet turned upwards". Now, in the Harivamśa and some Purānas, Kochab is called Uttānapāda, while Polaris in the Mahābhārata is referred to by the patronymic Auttānapāda, indicating that the star that previously was closest to the pole is the "father" of the present polestar. ${ }^{189}$

\footnotetext{
${ }^{187}$ Falk 1994.

${ }^{188}$ E.g. in the Atharvavedic Skambha-hymns, and in Śvetāśvatara Upaniṣad 3.9, where the Purușa "stands like a tree established in heaven" (vrkșa iva stabdho divi tișthaty). Here I would also like to mention Bṛhadāranyaka Upaniṣad 5.5.3, where the Purușa's head is said to be the earth, his arms, the atmosphere, and his legs (lit. "support", pratisththa), the sky.

${ }^{189}$ Ibid. p. 12; Liebert, op. cit., p. 165ff; Böhtlingk \& Roth, s.v. The notion that night constitutes a temporary inversion of the ordered cosmos is reminiscent of the conception of the underworld of the dead as a topsy-turvy place where everything is the opposite of what we find in the world of the living: day here is night there, cattle eat humans, up is down etc. (On this motif in India and elsewhere, see Lommel 1978, pp. 211-27.) An inversion of up and down is referred to in the Mbh, 1.13.11, where Jaratkāru finds his ancestors hanging upside down in a cave. Oberlies (1998, p. $465 \mathrm{n}$. $58 ; 2012$, p. 488 n. 2) has briefly commented on the possible connection to the tree held upside down by Varuna, but, being skeptical as to Kuiper's theory of a nocturnal inversion of the cosmos, he has not elaborated on the possibility of an association of night with the world of the dead. Such a connection has, however, been forcefully argued by Kuiper (1977, pp. 67-77; 1983, pp. 68ff, 80ff), who connects Varuna's role as the god of night with his being the ruler of the underworld, sometimes together with Yama, the king of the dead (RV 10.14.7, 123.6). Night and death both constitute deviations from the cosmic order, a notion which may well be expressed through the image of an actual overturning of the cosmos.
} 
If these conjectures are right, they add further support to the theory - forcefully argued by Thieme, Kuiper, and Witzel - of a special association of the world-tree with the nocturnal sky, and the celestial pole. This tree stands at the source of the Milky Way (the celestial Sarasvatî-river); at its top (or upturned bottomside?) stands the heavenly jar amid the Seven Seers, seated close to the pole; in the same tree sits Soma, the Moon, distributing the ambrosia of the gods, and here is perhaps also the night-sun. This association with the nightsky is easy enough to understand: the world-axis is typically believed to be located in the middle of the world, at a point which can only be determined at night, through the movements of the stars. In fact, observation of the rotation of the stars around the fixed celestial pole may well have been what gave rise to the conception of an axis mundi in the first place. ${ }^{190}$ Among peoples of subarctic Eurasia, where beliefs in a world-axis are especially widespread, ${ }^{191}$ the axis is conceived of variously as a tree or a pillar or wooden post, the polestar being typically said to be immediately above it, in its crown or as a nail gleaming from the top of the post.

It is difficult to say anything definite concerning the relationship between the Rgvedic ambrosial jar, which yields rain ${ }^{192}$ (containing the soma-juice), and the moon, which later becomes the celestial Soma as well as the source of rainfall. ${ }^{193}$ (That there is no evidence for the moon being identified with Soma before the late hymn RV 10.85

\footnotetext{
${ }^{190}$ Hultkrantz (1996) has pointed out that the turning of the sky around a fixed point is most clearly visible far up in the northern hemisphere, which would explain the prominence of beliefs in a world-axis among subarctic peoples in Eurasia and North America, as compared to the scarcity of such conceptions in, for instance, the ancient Mediterranean civilizations. Possibly, these circumstances may explain the absence of a world-tree in younger Indian mythology, and the early transposition of the tree to heaven, as the early Indo-Aryans migrated southwards. The presence of conceptions of an inverted world-tree among North and Central Asiatic peoples also suggests that the Vedic Aryans brought the belief in a world-tree with them to the South Asian subcontinent from more northerly regions.

${ }^{191}$ Cf. Hultkrantz, op. cit.; Holmberg, op. cit.; Paulson in Paulson, Hultkrantz \& Jettmar 1962, pp. 28-32; Eliade 1964, chap. 8.

${ }^{192}$ Lüders 1959, p. 372: "Der Regen stammt im letzten Grunde aus dem Somaquell im höchsten Himmel".

${ }^{193}$ The question was raised but left aside by Kuiper 1983, p. 146.
} 
is more or less uncontested. ${ }^{194}$ ) Although it is sometimes stated in secondary literature that the moon is a receptacle containing the soma, from which gods or Ancestors drink, this seems in fact to be a postVedic conception; ${ }^{195}$ while Middle Vedic texts frequently state that the moon, king Soma, is "the food of the gods", no vessel is mentioned. ${ }^{196}$ The connection between Soma (not yet identified with the moon!) and rainfall is a well-established belief already in the $\mathrm{RV} ;{ }^{197}$ and the notion that the sacred juice descends to earth with the rain goes back to Proto-Indo-Iranian times. ${ }^{198}$ Now, is this conception independent from that of the ambrosial rain-jar? I think not. The soma (PIIr *sáuma-) clearly was thought to originate in heaven, in a spring or receptacle situated in the celestial ocean, whence it reached earth with the rain. ${ }^{199}$ As the jar or spring becomes obsolete in Middle Vedic beliefs, it would make sense that the moon, now identified with the celestial Soma of the RV, has taken over at least its most important functions (as the source of rainfall and the nourishment of the gods).

\footnotetext{
${ }^{194}$ Criticisms of Hillebrandt's (1999: I) view that the moon is already identified with Soma throughout the RV include Oldenberg 1967, pp. 49-62; Macdonell 1897, p. 113; Vodskov 1897, pp. 276-87; Keith 2007 [1925], p. 171; Lüders 1959, pp. 698-701; Gonda 1985.

${ }^{195}$ Examples from epic and classical Sanskrit texts in Gonda 1985; Hillebrandt 1999: I, pp. 195-97.

${ }_{196}$ The question has been dealt with by Klaus, op. cit., pp. 148-51, who notes that the earliest mention of the moon as a receptacle for the soma seems to be JB 1.136, speaking of the "juice" (rasa-) that is collected in the moon. In the rather innovative arrangement of $S \mathrm{vB}, 6.1-2$, the earth, atmosphere, and sky are said to be three bowls (pātra-), which are drunk empty successively by the gods for three five-day periods during the fortnight of the waning moon; the remaining "sixteenth part" (the new moon) descends on earth and enters plants, trees, cattle, and brahmins. Here the sixteen-part moon (sodaśakalo vai candramāh ) appears to be the content of the three bowls, rather than the receptacle itself.

${ }^{197}$ Lommel 1978, pp. 314-23; Lüders, op. cit., pp. 339-441.

${ }^{198}$ Oberlies 1998, p. 245 n. 472; 2012, pp. 77, 81, 191.

199 Thus Lüders.
} 


\section{Honey, ambrosia, and soma}

The association of both the jar and the moon with night also speaks in favor of this conclusion. ${ }^{200}$ It is clearly closely connected with the conception of a celestial ocean, which, as has been seen, is located in the nocturnal sky. But rain, of course, does not fall only at night, even in highly speculative ancient cosmologies. The "natural basis" of the notion of a reservoir of rainwater in the moon or in Ursa Maior must be something else. I think Gonda was right in identifying this basis, when he wrote, concerning the moon and rainfall:

This popular belief may no doubt be connected with old and widespread conceptions about the close relations between nectar or ambrosia on the one hand and honey, honey-dew, dew on the other. These moistures were believed to come down from the sky or from the atmosphere (ordinary honey being not rarely conceived of as a sort of dew), or to be sent down by the moon. As ideas concerning the salutary honey and the intoxicating mead were similar to those attached to the 'draught of immortality' enjoyed by the gods and as the soma was in all probability the Indo-Iranian substitute for mead or at least its counterpart, the inference that there existed a reservoir of soma in the moon cannot be regarded as far-fetched. ${ }^{201}$

We noted above (in a footnote) that dew seems to be meant in the passage 5.85.3, where Varuna pours out the heavenly jar and moistens the barley "like rain" does the earth (yávam ná vrștír vy ùnatti bhtuma). Dew is not seen as it falls, but can be seen lying on grass and plants in the morning; the natural inference would be that it has fallen in the night or shortly before daybreak. ${ }^{202}$ "Honeydew" ${ }^{203}$ as a poetical and mythological image is known from ancient Greece ${ }^{204}$ and

\footnotetext{
${ }^{200}$ Cf. Bodewitz 1982, p. 48 n. 22 , commenting on Kuiper's theory of the rain-jar in the ocean of the nocturnal sky: “... the connection between rain and the (likewise nocturnal) moon is a well-known theme in Vedic India".

${ }^{201}$ Gonda, op. cit., p. 58.

202 On the moon as the origin of dew in classical literature, cf. Boedeker 1984, pp. 589; Roscher 1883, p. 79.

203 "In reality honeydew is the sweet viscid juice exuding from leaves punctured by insects and the sweet excretion of aphids and allied insects." (Gonda, op. cit., p. 45 n. 49.) In more detail: Roscher, op. cit., pp. 13-16.

${ }^{204}$ Roscher, op. cit., pp. 9-10, 13-19; Boedeker, op. cit., pp. 45-9. For beliefs and practices concerning honey in ancient Greece, cf. Roscher, op. cit.; Ransome 2014 [1937], chaps. 9-12.
} 
Scandinavia, ${ }^{205}$ and, indeed, from Vedic India, ${ }^{206}$ where the Aśvins, gods associated with the morning twilight and noted for their fondness of honey, are said to sprinkle the earth with honey from their "honeywhip" (káśa mádhumatī) or from a skin-bag (dŕti-) as they arrive in their flying chariot; this bag may conceivably be a duplication of the heavenly jar. ${ }^{207}$

That the Indo-Iranian *sáuma- more or less succeeded the hydromel, the ancient cult-drink of the Indo-Europeans, is fairly uncontroversial. ${ }^{208} \mathrm{~A}$ vestige of more ancient cult-practices has been seen in the frequent designation of soma as mádhu-, honey or mead (Proto-Indo-European *medhu-). ${ }^{209}$ The use of honey in Vedic ritual has been explored by Hillebrandt ${ }^{210}$ and, more recently, Oberlies, ${ }^{211}$ who also compares its use in some domestic rites (notably in the śräddha or Ancestor worship, and the guest-reception ceremony, argha-) with analogous practices in ancient Greece. Obviously, soma has taken the place of the honey-drink not only in ritual, but in myth and cosmology as well; the well-known myth of the bird stealing the

\footnotetext{
${ }^{205}$ It is mentioned in Gylfaginning, where the honeydew is said to fall from the cosmic tree Yggdrasill. Cf. below, and De Vries 1957, p. 406.

${ }^{206}$ Oldenberg 1894, pp. 208-9 n. 4 (followed by Lüders, op. cit., p. 374); Vodskov, op. cit., pp. 519-22. Of interest is a passage in Aelianus, De natura animalium 15.7, which describes how honey (méli) falls on pastures in India in the form of dew (drósos); cattle and sheep are led to these pastures and consume the dew as they graze, and their milk becomes so sweet that there is no need to sweeten it with honey. (Roscher, op. cit., p. 33.) This description is highly reminiscent of the Middle Vedic notion that the moon, king Soma, enters the plants at new moon, to be consumed by cattle and blending with their milk (for which cf. Lommel, loc. cit.; Wilden, op. cit., pp. 77-94)

707 This receptacle is, as mentioned, carried by various gods associated with rain (the Maruts, Parjanya). In 5.83.7 (on which cf. Lüders, op. cit., p. 381), Parjanya carries a rain-yielding dirti- in his chariot, which in the next verse is, however, designated as $k o ́ s ́ a-$, the most common word used for the rain-vessel.

${ }^{208}$ Cf. e.g. Gonda, op. cit.; Oberlies 1998, pp. 244-46; 2007; 2012, pp. 59, 76 (with references).

${ }^{209}$ Oldenberg 1894, pp. 367-68, while considering it beyond doubt that mead was the sacred drink of the Indo-Europeans, rejected the idea that the designation mádhu-for soma would be a survival from older practices, suggesting instead that it is a poetical expression used for any pleasant beverage or substance; he also considered the honey that was mixed with the soma-drink to be a simple sweetener. His complete rejection of any connection with Indo-European cult-practices does not, however, seem to have met with great acceptance (cf. e.g. Oberlies, op. cit., p. 244 n. 468).

${ }^{210}$ Hillebrandt 1999: I, pp. 316-27; cf. also Lüders, op. cit., pp. 369-79.

${ }^{211}$ Oberlies 2007.
} 
soma from heaven ${ }^{212}$ has a number of correspondences in the mythologies of other Indo-European peoples, most notably in the Norse myth of the theft of the mead of poetry, as told in the Prose Edda. ${ }^{213}$ I think that the heavenly spring, well, or vessel, too, originally did not contain soma. Although there are some indications that a spring of *sáuma- was envisaged already in Proto-Indo-Iranian times, ${ }^{214}$ the fact remains that the spring or vessel is very seldom said, in the RV and AV, to contain soma; instead, it yields honey, ghee, and curds, substances which are also said to constitute the streams of heaven. ${ }^{215}$ While soma is not infrequently referred to as honey or milk, it still seems odd that it is but rarely mentioned under its real name in connection with the spring. In fact, the liquids flowing from the spring correspond to those used in the ancestor worship, where they are poured as libations in furrows, ditches, and streams; ${ }^{216}$ and this is well in keeping with the fact that the blessed dead are said to feed on the streams flowing from the spring. ${ }^{217}$ Honey mixed with dairy products and water also plays a role in some of the domestic rites, ${ }^{218}$ as mentioned above; these rites, like the ancestor worship, are generally of a conservative nature and may be very ancient. It would seem, then, that the image of a spring of honey situated in heaven is part of an ancient, perhaps Indo-European, mythological heritage which predates the soma cult. Originally honey and, probably, milk or its products were thought to originate in the rivers feeding the ocean of heaven,

\footnotetext{
${ }^{212}$ Among the numerous studies of this motif, mention may be made of just a few: Kuhn 1859 (a comparative Indo-European study); Johansson 1910; Charpentier 1920; Knipe 1967 (comparing Indo-European as well as ancient Near Eastern materials); Schneider 1971; Feller 2004, chap. 4; Oberlies 1998, pp. 244-46; 2012, pp. 188-91. For comparative (mainly Indo-European) perspectives, see also Doht 1974; West 2007, pp. 158-60.

${ }^{213}$ Cf. Doht, op. cit.; De Vries, op. cit., pp. 180-85.

${ }^{214}$ Oberlies 1998, p. 245 n. 472.

${ }^{215}$ Cf. Lüders, op. cit., pp. 351-59 ("Vermischungen der Ingredienzien der Himmelsflut").

${ }^{216}$ This was pointed out already by Rönnow (1927, chap. 2). On honey in the ancestral rites, cf. also Oberlies 2007, pp. 148-50.

${ }^{217}$ Cf. the examples given above, esp. AV 18.4.35-6 (part of a funerary hymn), where the spring is said to be fed by the oblations offered to the dead; in st. 30, it is called a jar with four apertures (kaláśam cáturbilam). The close association of the Ancestors with the (celestial) Sarasvatī (cf. st. 45-7, and Hillebrandt 1999: II, pp. 211-12) is certainly of relevance here, as this river is fed by the heavenly spring.

${ }^{218}$ E.g. in the madhuparka- or "honey-mixture" presented to guests.
} 
flowing from the celestial spring, and to fall to earth with the rain or dew (honeydew!). Eventually, these conceptions came instead to center around the soma.

\section{The Indo-Iranian heavenly tree}

While the notion of a celestial mead or honey on which the gods feed is, in all likelihood, Indo-European, the case for an Indo-European cosmic tree is considerably shakier. It is true that there are similarities between the Vedic cosmic aśvattha and the ash Yggdrasill of Old Norse mythology; from the branches of this ash, "honeydew" falls on the earth, ${ }^{219}$ and under its roots a number of wells are situated: Urdr's well, containing a white, shiny liquid which nourishes the tree; Hvergelmir, which is the source of a number of rivers; and Mimir's well, containing wisdom-bestowing mead. A comparison was early on made with the tree Somasavana, "flowing with soma". ${ }^{220}$ Uno Holmberg, however, cast serious doubts on the alleged Indo-European origin of such images, pointing out not only the extreme prominence of beliefs in a world-tree or tree of life among non-Indo-European peoples of North Asia, but also the fact that these trees are often said to be dripping of honey or honeydew, or with a milky fluid, and to be standing at the source of rivers. ${ }^{221}$ Sometimes, the tree grows in the middle of a mythical ocean which, among some peoples (Yakuts, Altai-Tartars), consists of milk and is situated in a celestial paradise. ${ }^{222}$ To be sure, the conception of an ambrosial tree may be Proto-Indo-European, but not exclusively so; rather, the elixir-yielding cosmic tree is part of a larger, Eurasian mythological complex. ${ }^{223}$

\footnotetext{
${ }^{219}$ Cf. Gylfaginning, tr. Faulkes 1987, p. 19: "The dew that falls from it on to the earth, this is what people call honeydew, and from it bees feed."

${ }^{220}$ Cf. e.g. Kuhn, op. cit., p. 130ff; Roscher, op. cit., pp. 20-21; De Vries, op. cit., p. 409; Keith, op. cit., p. 172 n. 2; now also Oberlies 1998, p. 245 n. 472; West, op. cit., p. 346.

${ }^{221}$ Holmberg 1996 (originally published 1922).

${ }^{222}$ Op. cit., pp. 97-8; Paulson, op. cit., p. 32. We leave aside the possibility (brought up by Holmberg) of pan-Indian influence (cf. the ocean of milk in Purānic cosmology and in the myth of the "churning of the ocean"); in the Tatar myth cited by Holmberg, p. 97, such influence may be seen in the name of the eagle (Garuda) perched on the tree, but this image is widespread, as we have seen, and only the name may be of foreign origin.

${ }^{223} \mathrm{Cf}$. also the cautious remarks in West, op. cit., p. $345 \mathrm{ff}$.
} 
We stand on safer ground when comparing the Vedic world-tree to similar mythical trees in ancient Iran. In Yašt 12.17 we find mention of "the tree of the saêna bird" (vanam yąm saēnahe), which stands in the midst of the mythical sea Vourukaša, has "good remedies" and is called "All-remedies" (vīspō.bǐs). All seeds are deposited in it. The bird reappears in Pahlavi texts, ${ }^{224}$ where it is called Sénmurw (Avestan mərayō saēnō, "the bird saenna-", where saèna-corresponds to Vedic śyená-). It is said to perch on the "tree of many seeds", breaking off twigs each time it alights on it; from these, seeds are collected by another bird, Cīnāmrōš, and deposited in the rainwater which is brought down on earth by the star Sirius (Tištar). (Mēnōg $\overline{1}$ Xrad $61.37-41 i^{225}$ cf. Bundahišn 27.3. ${ }^{226}$ ) Another tree said to stand in Vourukaša is called Gaokərəna or Gokard, or the tree of "the white hōm (haoma)", ;27 all who eat from it become immortal (Bundahišn 18.1; 27.4). The evil spirit, Ahriman, once created a lizard and made it attack the tree, though without success (Bundahišn 18.2ff). Of special interest is the notion that it stands at the source of the river Ardvīsūr (Bundahišn 27.4); this is the Avestan river (and goddess) Arəduū Sūrā Anāhitā, the reincarnation of the old Indo-Iranian celestial river and the counterpart of the Vedic Sarasvatī. ${ }^{228}$ Reduplication of motifs may be responsible for the formation of two trees and two birds.

Here too, comparisons have been made with the Norse worldash, in whose crown an eagle is perched and whose roots are gnawed by the dragon Niððhöggr. ${ }^{229}$ Again, however, North Asiatic cosmologies cast doubts over the significance of such comparisons. An eagle is frequently found at the top of the world-tree in these belief-systems; ${ }^{230}$ eagles being sacred to Siberian peoples, the eagle

\footnotetext{
${ }^{224}$ Cf. Schmidt 1980; Carnoy 1964 [1917], pp. 289-91.

${ }^{225}$ Cited by Schmidt, op. cit., p. 6.

${ }^{226}$ Tr. West 1880.

${ }^{227}$ Compared to the Vedic materials by, e.g., Viennot, op. cit., pp. 29-30; Lommel 1978, pp. 521-22; Oberlies 2012, p. 191.

${ }^{228}$ Cf. Lommel 1978, pp. 305-13; Witzel 1984, pp. 218, 226; now also Oberlies 2012, pp. $77-8$.

${ }^{229}$ Cf. in general West 2007, pp. 346-47.

${ }^{230}$ Many examples are given throughout Holmberg's study. The image is also known from the ancient Near East: Wensinck 1921. Pairs of birds perched on trees occur in art throughout the ancient world (Wilke 1922); however, as the mythical, cosmological, or symbolical contexts are almost always lost, it seems hazardous to bring such evidence into our discussion. (Wilke's view that the birds represent sun
} 
perched on the cosmic tree often appears as a creator-figure or a weather-divinity. ${ }^{231}$ If we confine our comparisons to the Indo-Iranian sphere, however, the possibility of a common mythological heritage would seem to increase significantly. The tree called "All-remedies" or the "tree of many seeds", and the tree of the "white haoma" (Vedic sóma-), both call into mind the tree Somasavana or the celestial aśvattha on which grows the healing kustha-herb. While the motif of the tree dripping with honey or elixir is a widespread one and not (or not only) Indo-European, a tree associated with soma/haoma would likely be the specifically Indo-Iranian incarnation of this motif. The remedy-bearing tree is also said to stand in the middle of Vourukaša, which is often held to be related to the Vedic celestial ocean. Oberlies has recently sought to reconstruct parts of a Proto-Indo-Iranian cosmology in which * sáuma- originated in heaven, in a spring in the midst of the celestial ocean. This ocean was fed by a river springing from the world-tree. ${ }^{232}$ Other conceptions which may go back to the time of Indo-Iranian unity locate the *sáuma- in heaven on the top of the world-tree (which is the same as the fig-tree in RV 1.164.20-22), or on a world-mountain which could likewise serve the role of an axis mundi. From its heavenly location, the *sáuma- descended to earth with the rain. ${ }^{233}$

It seems safe to conclude, especially in consideration of the Iranian parallel, that the honey-eating bird originally had nothing to do with the moon. In Proto-Indo-Iranian times, there existed an image of a supernatural bird settled on the cosmic tree and somehow involved in the descent of the drink of immortality from heaven to the earth. In late Rgvedic times, an identification of the moon with the celestial Soma developed; if one of the birds in the riddle is to be identified as the moon, it is not yet identical with Soma, but rather is thought to swell as a result of consuming the celestial beverage. The close connection between the world-tree (and the heavenly jar) and the

and moon is a piece of speculation.) The same holds for the old Bulgarian relief adduced by Thieme (1949, p. 73), which shows two peacocks with a plant between them, on which one of them is pecking. While the peacocks may point to an ultimately Indian origin of this motif, a connection with the Vedic riddle of the two birds is too much of an assumption.

${ }^{231}$ Sternberg 1930

232 Oberlies 1998, p. 245 n. 472; 2012, pp. 76-7, 81, 190-91, 433 n. 164.

233 Ibid. 
nocturnal sky may further have facilitated an identification with the moon. In the Iranian corpus, however, neither haoma nor the bird are associated with this luminary.

\section{The honey-eating bird(s) and the soma-stealing eagle}

Some scholars have maintained that the fig- or honey-eating birds in the riddle-hymn are closely related to the eagle in the myth of the theft of the soma. ${ }^{234}$ The same would hold for one or both of the birds in Iranian texts, connected with haoma or celestial remedies. A fair amount of analogous myths exists throughout the Indo-European world; the most famous being the Old Norse tale of Odin's theft (in the shape of an eagle) of the mead of poetry, which, as Kuhn noted long ago, probably preserves an older form of the original myth than the story of the theft of the soma. In the image of birds flying toward the tree that rises to the sky, seeking the "honey" which is also called amita-, we would then have a vestige of the old myth.

There are certain difficulties involved in these comparisons. The image of a bird perched on the cosmic or celestial tree - where he has his perpetual seat, according to the Iranian texts - is not too easily reconcilable with the myth, taking place in remote times, of a bird fetching the drink of immortality from heaven. As mentioned earlier, the image of the eagle on the top of the world-tree is very widespread among North and Central Asiatic peoples, and may very well have been picked up by the Indo-Iranians; if so, it would have no relationship to the Indo-European myth of the mead-stealing eagle. Furthermore, no tree appears either in the Vedic or other IndoEuropean versions of this myth (although Yggdrasill is closely associated with mead and honey).

It is, however, hard to deny that the association of bird and divine drink in both cases is unlikely to be coincidental. While a single bird is said to have fetched the drink of immortality in ancient times, we also meet with the notion that the elixir is continually brought from some distant location by several birds: thus Yasna 10.10-11, where the birds are said to bring the haoma from the worldmountain Haraitī, where it grows, to adjacent mountains. This has been compared to the famous passage in the Odyssey, 12.63f, telling

${ }^{234}$ Kuhn, op. cit., pp. 126-27; Johansson, op. cit., pp. 29-30; Lommel, op. cit., p. 517. 
of the doves which bring ambrosia to Zeus through the dangerous passage between the Symplegades or clashing rocks. ${ }^{235}$ In the Yasna passage, neither the mountains nor the birds seem to be of the ordinary kind; for one mountain is called upairi.saenna, "above the [flight of the] saenna bird", corresponding to upariśyena-, which is the name of a "heavenly world" (svarga- loka-) in JB 3.66. ${ }^{236}$ A rock (ádri-) from which the syená- brings the soma is referred to in the RV $(1.93 .6) ;{ }^{237}$ and in the Prose Edda, the mead of poetry is stolen by Odin from inside the mountain Hnitbjörg. These Iranian and Old Norse parallels support the view ${ }^{238}$ that the "rock" from which the bird steals the soma according to RV is not, as some have suggested, to be identified with the earthly mountains on which the soma-plant grew (the Müjavant of Vedic texts), but belongs to the realm of mythology. It is the primordial mountain, from which the world-tree rises. ${ }^{239}$

We have seen that the AV locates the remedy-bearing tree, associated with soma and amrta-, on a Himalayan mountain-top reaching to the "third heaven"; the words suparnasúvane giráu (AV 5.4.2), "upon the mountain, the brooding-place of the eagle" (Bloomfield), may possibly refer to some mythical association with eagles, or falcons. ${ }^{240} \mathrm{We}$ have also seen that the words "in the third heaven (from here)" recur in Middle Vedic accounts of the bird's theft of the soma; and though no tree is mentioned there, an aśvattha-tree called "flowing with soma" is located in this third heaven according to Chāndogya Upanișad 8.5.3.

One possible reminiscence of the cosmic tree may be found in the post-Vedic version of the soma-stealing myth found in the Mbh (1.14-30) and the Suparnākhyāna (Sup.). ${ }^{241}$ This includes a series of episodes seemingly without connection to the central motif of the theft

\footnotetext{
${ }^{235}$ Oberlies 1998, p. 245 n. 471.

${ }^{236}$ Ibid., p. 246 n. 475.

${ }^{237}$ Elsewhere (5.85.2), Varuna is said to have placed the soma on "the rock" (adadhāt sómam ádrau), much like an unnamed god is said to have fashioned haoma and placed it on Haraitī in Yasna 10.10.

${ }_{238}$ Oberlies 2012, p. 190.

${ }^{239}$ Ibid. pp. 190-91; cf. Kuiper 1983, Index, s.v. "Cosmic mountain", "Primordial hill", "Primordial mountain". Similarly Knipe, op. cit., p. 357, followed by Feller, op. cit., p. $161 \mathrm{n}$. (the mountain being the heaven).

${ }^{240}$ The same root $s u$ - "to propagate, give birth" occurs in a similar context in RV 1.164.22, where the suparnás are said to breed (súvate) on the tree (vrkșé).

${ }^{241}$ Ed. Charpentier 1920.
} 
of the soma, in which the eagle, Garuda, before his excursion to heaven, first consumes an entire non-Aryan tribe of Nișādas, then goes on to seize an elephant and a giant tortoise and settle on a gigantic tree, called Rohina or Rauhina, where he intends to eat them (Mbh 1.25.31ff; Sup. 7.3ff). This tree is, interestingly, said to stand in water; in a ford, among the jewel-studded "divine trees", "washed by sea-water" (devavrkșānn ... sāgarāmbuparikșiptān, Mbh 1.25.27, 30), or on the shore of the ocean (anūpam sindhurājasya; Rāmāyaṇa 3.33.27, Baroda rec., where the tale is briefly recapitulated; the tree is here specified to be a nyagrodha). As he settles on a "huge branch extending a hundred yojanas" (mahāśākhā śatayojanam āyatā, Mbh 1.25.32), however, the tree shakes and the branch breaks; on the branch dwell (!) the Vālakhilya seers, and in order to save them, Garuḍa has to seize the branch before it hits the ground.

These curious adventures have no bearing on the rest of the story, and it has been suggested that they are mythical residues which were no longer understood when these texts were composed. ${ }^{242}$ Garuda perched on the branch of the enormous tree has been compared to the eagle or falcon on the celestial tree in Iranian tradition. ${ }^{243}$ That some elements of the episode are of great antiquity is made likely by the fact that Garuḍa's devouring the Nișādas has a parallel in the Bundahišn's account of the bird Cīnāmrōš's pecking the enemies of Iran. ${ }^{244}$ In the breaking of the branch on which Garuda alights we may conceivably have a faint echo of a tradition analogous to that of the Senmurw's breaking off a thousand twigs from the tree "of all remedies" each time it alights on it.

We mentioned at the beginning of this article that there is some doubt as to whether the birds in the Rgvedic riddle really are raptors. While the fact that suparná- is sometimes used interchangeably with śyená- would seem to favor a connection with the saenna on the remedy-bearing tree, the problem remains that raptors don't eat fruit. One solution is to follow Thieme in dismissing any "vollständige zoologische Genauigkeit" in the riddle; taking it to be composed of more or less stereotyped images from the poet's repertoire, rather than based on actual observations of the behavior of animals. "Honey" and

\footnotetext{
${ }^{242}$ Johansson, op. cit., p. 29; Lommel 1978, pp. 512-13.

${ }^{243}$ Lommel, loc. cit.

${ }^{244}$ Schmidt 1980, pp. 6, 80 n. 12.
} 
possibly "fig" were used for denoting soma; and the myth associated a bird of prey with the soma's descent to earth. When composing the riddle of the birds, the poet may have chosen to use the unspecific suparná- throughout for denoting the birds, thus eliminating the difficulties that a fig-eating śyená- would have given rise to. In this way, the soma-snatching raptor of the myth was subtly transformed into a frugivore of ambiguous species.

In conclusion, there are some indications that the motif of the bird of prey perched on the tree of life, and the myth of the somastealing eagle, are but two different sides of the same mythologem. The bird sitting on the tree and distributing "honey" does in fact fill the same function as the bird that brought the soma to the gods, even though the latter event is assigned to primordial times. The many birds which continually fetch soma from the cosmic mountain or tree (Yasna 10.11, RV 1.164.21-22) may be the stars, as some scholars have suggested; but as mythologems it is clear that they are simply the original mythical bird in multiplied form. ${ }^{245}$ The underlying conception is that the soma is located at an inaccessible point in the sky, in the "third heaven", at the top of the cosmic tree, whence it can be fetched only after a long and difficult journey through the air. In st. 21-22 of the riddle hymn, this mythical image has been employed as a metaphor for the search for knowledge or wisdom: though the birds all shriek for the "share of the amrta-", only he who "knows the Father" may reach the "sweet fig" at the top of the tree.

\section{Conclusion}

We have tentatively followed the view of Hillebrandt and Kuiper, who saw the two birds in RV 1.164.20 as sun and moon; the bird that eats the "sweet fig" being the moon swelling from absorbing the ambrosia or celestial soma, while the bird that simply "watches" is the sun, which is characterized by all-penetrating vision and is not infrequently described as a bird (suparná-) gazing down upon earth. Support for these conclusions can be found in passages like 10.114.3-5 and 10.85.18-19, which employ imagery and phrasing reminiscent of that

\footnotetext{
${ }^{245}$ The notion of "reduplications" of mythological motifs, which may be produced on different "levels" (etiological, cosmological, epic etc.), is well-known from the structuralist study of myth; cf. e.g. Meletinsky 1998, pp. 211-12.
} 
found in the "riddle" of the birds. The "fig" or "honey" is the amirtaor soma; the tree on which the birds are perched is the world-tree, which is also in other Vedic texts described as a fig-tree. The many birds in 1.164.21-2 are difficult to identify with any certainty, but they may be the stars (Thieme, Hillebrandt), perhaps as the souls of the blessed dead (Hillebrandt). The motif of a distribution of the amrtaappears in st. 21 as well as in 10.114.3 and 10.85.19 (where the distributor is the moon, identified with Soma), and in the Yajurvedic mantra TS 4.2.9.1; it is possible to infer that the fig-eating bird in 1.164.20 is not merely eating, but also distributing the amrta- among the other "birds", perhaps in the way an adult bird feeds its young. This would be the "Father" and the "mighty guardian" mentioned in the riddle, knowledge of whom is required for a share of the "honey".

In the heaven there is a spring or a jar containing the celestial waters (Lüders, Kuiper); the soma is within these waters and reaches the earth when the jar is poured out and the waters fall down as rain. Kuiper thought that this jar is situated in the world-tree and is turned upside down and poured out by Varuna (RV 5.85.3) in the night, when the tree stands in an inverted position (1.24.7). Leaving aside Kuiper's conjecture that the jar must be located among the roots of the tree, we suggested that the fig at the "top of the tree" in the riddle of the birds should be connected with the heavenly spring or vessel. Following Witzel's identification, based on AV 10.8.9 and Bụhadāraṇyaka Upanișad 2.2.3, of the jar as the asterism called the "Seven Seers" (Ursa Maior), we pointed out that the above-mentioned TS 4.2.9.3 contains a variant form of the Atharvavedic stanza, in which the seven stars of that constellation are associated with the "honey-making bird" nesting on the "golden reed", presumably the world-tree; again confirming the association of "honey" or ambrosia, jar, bird, and tree. The identification of the jar with the Seven Seers confirm an association of the world-tree with the nocturnal sky, as suggested by Thieme and Kuiper. This would lend support to the view that one of the two birds is the moon; it is harder to reconcile with the identification of the other bird as the sun, though we have seen that the sun, in the RV, is thought to travel unseen through the dark nightsky.

In the rest of the article, we explored the motif of the cosmic or celestial tree in Vedic and later literature, and its parallels in Iranian and other Indo-European, as well as non-Indo-European (North and 
Central Asiatic), traditions. We have seen that the motifs of the inverted world-tree, of an eagle perched on top of the tree, and of honey or elixir dropping from the tree or flowing in streams from a spring at its roots, recur throughout the Eurasian world. The notion of a tree standing in the celestial ocean and associated with *sauma-, and with a bird of prey, most likely goes back to Proto-Indo-Iranian times, as several scholars have suggested. As for the relationship between this bird and the falcon or eagle fetching the soma or haoma- from a mythical mountain, according to a tale with parallels especially in Old Norse mythology (Kuhn, Doht, Knipe), we suggested that they may be closely related, being the mythological and cosmological expressions of the same basic idea: that of a supernatural bird bringing the divine beverage from heaven and distributing it among the worthy.

\section{Sources}

Āpastamba Śrautasūtra. The Śrauta Sütra of Āpastamba, belonging to the Taittirīya Samhitā with the Commentary of Rudradatta. Ed. R. Garbe. $2^{\text {nd }}$ revised ed. by C. G. Kashikar, New Delhi: Munshiram Manoharlal, 1983.

AV: Atharvaveda (Śaunaka). Atharvaveda Samhitā: Sanskrit Text, English Translation, Notes \& Index of Verses. English Translation according to W. D. Whitney and Bhāsya of Sāyanāācārya, ed. K. L. Joshi, Delhi: Parimal Publications, 2004. Partial transl. by Maurice Bloomfield, Hymns of the Atharva-Veda, Oxford: Clarendon Press, 1897.

AVP: Atharvaveda (Paippalāda). The Paippalāda Samhitā of the Atharvaveda. Volume one: consisting of the first fifteen Kändas, ed. Dipak Bhattacharya, Calcutta: The Asiatic Society, 1997.

Brhaddevatā. Ed. and tr. A. A. Macdonell, The Brhad-Devatā Attributed to Śaunaka. I-II. Cambridge Mass.: Harvard University Press, 1904.

JB: Jaiminīya Brāhmaña of the Sāmaveda. Eds. R. Vira and L. Chandra, Delhi: Motilal Banarsidass, 1986 [1954]. 
JUB: Jaiminīya Upaniṣad Brāhmaṇa. "The Jāiminīya or Talavakāra Upaniṣad Brāhmaṇa." Ed. and tr. Hanns Oertel. Journal of the American Oriental Society 16, pp. 79-260.

Kathāsaritsāgara: The Kathâsaritsâgara of Somadevabhatta. Ed. by Pandit Durgāprasād \& K. P. Parab. $4^{\text {th }}$ edn. Bombay: NirnayaSagar Press, 1930.

Mbh: Mahābhārata. 19 vols. Eds. V. S. Sukthankar et al. Poona: Bhandarkar Oriental Research Institute, 1927-66.

MNU: Mahānārāyaṇa Upaniṣad. La Mahā Nārāyaṇa Upaniṣad. Édition critique, avec une traduction française, une étude, des notes et, en annexe, la Prānāgnihotra Upanișad. Tome premier: texte, traduction, notes. Ed. and tr. Jean Varenne. Paris: Éditions E. de Boccard, 1960.

MS: Maitrāyaṇī Saṃhitā. Yajurvedīya Maitrāyaṇī-Saṃhitā, ed. S. D. Satavalekar. Paradi: Svadhyaya Mandala, vikramīyasaṃvat 1998 (= 1942?).

MU: Maitrī (Maitrāyaṇīya) Upanișad. The Maitrāyaṇīya Upanișad: A Critical Essay, with Text, Translation, and Commentary. Ed. and tr. J. A. B. van Buitenen. 's-Gravenhage: Mouton \& Co, 1962.

Nirukta: The Nighantu and the Nirukta. Ed. and tr. Lakshman Sarup. Delhi: Motilal Banarsidass, 1967.

PB: Pañcaviṃśa Brāhmaṇa. Tāṇ dyamahābrāhmaṇa. 2 vols. Ed. A. C. Śāstri and P. Śāstri. Benares: Kāśi Sanskrit Series, 1935-36. Tr. W. Caland, Pañcavimiśa-Brāhmaṇa: The Brāhmaṇa of Twenty Five Chapters, Calcutta: Baptist Mission Press, 1931.

Rāmāyaṇa. 7 vols. (Ed. G. H. Bhatt and U. P. Shah.) Baroda: Oriental Institute, 1960-75.

RV: Rggveda. Rig Veda: A Metrically Restored Text. Eds. B. van Nooten and G. Holland. Cambridge, Mass.: Harvard University Press, 1994. Rig-Veda-Sanhita: The Sacred Hymns of the Brahmans together with the Commentary of Sayanacharya. 6 vols. Ed. F. Max Müller, London: W. H. Allen \& Co, 1849-74. 
RVKh.: R.gveda-Khilāni. Die Apokryphen des Rgveda. Ed. Isidor Scheftelowitz. Darmstadt: Georg Olms Verlagsbuchhandlung, 1966 [1906].

ŚB: Śatapatha Brāhmaṇa (Mādhyandina). Ed. Albrecht Weber. Varanasi: Chowkhamba Sanskrit Series No. 96, 1964 [1855]. Tr. Julius Eggeling, The Satapatha-Brâhmana According to the Text of the Mâdhyandina School. 5 vols, 1882-1900. Oxford: Clarendon Press.

ȘvB: Șaḍviṃśa Brāhmaṇa. Șadvimíśa Brāhmaṇa with Vedārthaprakāśa of Sāyaṇa. Ed. Bellikoth Ramachandra Sharma. Tirupati: Kendriya Sanskrit Vidyapeetha, 1967.

Sup.: Suparṇākhyāna. See Charpentier 1920.

TĀ: Taittirīya Āranyaka. The Taittirīya Aranyaka of the Black Yajur Veda with the Commentary of Sāyañācārya. Ed. Rajendralal Mitra. Calcutta: Asiatic Society of Bengal, 1872.

TB: Taittirīya Brāhmaṇa. Ed. Rajendralal Mitra. Calcutta: Bibliotheca Indica, 1859.

TS: Taittirīya Saṃhitā. Ed. Albrecht Weber, Indische Studien 11-12, Leipzig: Brockhaus, 1871-72. Tr. Arthur Berriedale Keith, The Veda of the Black Yajus School entitled Taittiriya Sanhita, 2 vols, Cambridge, Massachusetts: Harvard University Press, 1914.

Upanișads: The Early Upanișads: Annotated Text and Translation. Ed. and tr. Patrick Olivelle. New York: Oxford University Press, 1998.

Yašts: Ed. Karl F. Geldner, Avesta: The Sacred Books of the Parsis. Vol. II. Stuttgart: Kohlhammer, 1896. Tr. Herman Lommel, Die Yäšts des Awesta. Göttingen: Vandenhoeck \& Ruprecht, 1927.

\section{Secondary literature}

Agrawala, V. S., 1963. The Thousand-syllabled Speech: Being a Study in Cosmic Symbolism in its Vedic Version. I. Vision in Long Darkness. Varanasi: Prithivi Prakashan. 
Ali, Sálim, 1955. The Book of Indian Birds. $5^{\text {th }}$ revised edn. Bombay: The Bombay Natural History Society.

Austin, Christopher R., 2008. "The Sārasvata Yātsattra in Mahābhārata 17 and 18." International Journal of Hindu Studies Vol. 12, No. 3, pp. 283-308.

Bharadwaj, O. P., 1978. "Plakṣa Prāsravaṇa." Annals of the Bhandarkar Oriental Research Institute 58/59, pp. 479-87.

Bloomfield, Maurice, 1906. A Vedic Concordance. Cambridge, Mass.: Harvard University Press.

Bodewitz, Henk W., 1982. "The Waters in Vedic Cosmic Classifications." Indologica Taurinensia 10, pp. 45-54. 2000. "Classifications and Yonder World in the Veda." Wiener Zeitschrift für die Kunde Südasiens 44, pp. 19-59.

Boedeker, Deborah, 1984. Descent from Heaven: Images of Dew in Greek Poetry and Religion. Chico: Scholars Press.

Böhtlingk, Otto, and Rudolph Roth, 1855-75. Sanskrit-Wörterbuch. 17. St. Petersburg: Kaiserliche Akademie der Wissenschaften.

Bosch, F. D. K., 1990 [1964]. The Golden Germ: An Introduction to Indian Symbolism. New Delhi: Munshiram Manoharlal.

Brereton, Joel P., 1991. "Cosmographic Images in the Brhadāranyaka Upanișad.” Indo-Iranian Journal 34, pp. 1-17.

Brown, W. Norman, 1968. "Agni, Sun, Sacrifice, and Vāc: A Sacerdotal Ode by Dīrghatamas (Rig Veda 1.164)." Journal of the American Oriental Society Vol. 88, No. 2, pp. 199-218. (Repr. in India and Indology: Selected Articles by W. Norman Brown, ed. R. Rocher, Delhi: Motilal Banarsidass, 1978, pp. 5374.)

Caland, Willem, 1970 [1919]. Das Jaiminīya-Brāhmaṇa in Auswahl. Wiesbaden: Dr. Martin Sändig.

Carnoy, Albert J., 1964 [1917]. Iranian [Mythology]. (The Mythology of All Races Vol. VI.) New York: Cooper Square Publishers.

Charpentier, Jarl, 1920. Die Suparnasage. Uppsala: A.-B.

Akademiska Bokhandeln. 
Coomaraswamy, Ananda K., 1977. "The Inverted Tree." Selected Studies. I: Traditional Art and Symbolism. (Ed. R. Lipsey.) Princeton: Princeton University Press, pp. 376-404. [First publ. 1938.]

Dave, K. N., 2005 [1985]. Birds in Sanskrit Literature. $2^{\text {nd }}$ expanded edition, ed. by André Couture. Delhi: Motilal Banarsidass.

Delbrück, Berthold, 2009 [1888]. Altindische Syntax. New York: Cambridge University Press.

Deussen, P. 1906. Allgemeine Geschichte der Philosophie. Erster Band, Erste Abteilung. Leipzig: F. A. Brockhaus.

De Vries, Jan, 1957. Altgermanische Religionsgeschichte II. Berlin: Walter de Gruyter.

Doht, Renate, 1974. Der Rauschtrank im germanischen Mythos. Vienna: Verlag Karl M. Halosar.

Dumont, Paul-Emile, 1961. "The Full-Moon and New-Moon Sacrifices in the Taittirīya-Brāhmaṇa (Fourth Part): The Anuvākas 1-6 and 11 of the Seventh Prapāțhaka of the Third Kāṇda of the Taittirīya-Brāhmana with Translation." Proceedings of the American Philosophical Society, Vol. 105, No. 1, pp. 11-36.

Edsman, Carl-Martin, 1966. "Arbor inversa. Heiland, Welt und Mensch als Himmelspflanzen.” In K. Rudolph et al. (eds.), Festschrift Walter Baetke, Weimar: Hermann Böhlaus Nachfolger, pp. 85-109.

Ehlers, Gerhard, 2007. "Sieben Seher, sieben Wasser." In K. Klaus \& J.-U. Hartmann (eds.), Indica et Tibetica: Festschrift für Michael Hahn zum 65. Geburtstag von Freunden und Schülern überreicht. Vienna: Arbeitskreis für tibetische und buddhistische Studien, Universität Wien, pp. 145-50.

Eliade, Mircea, 1964. Shamanism: Archaic Techniques of Ecstasy. London: Routledge \& Kegan Paul.

1996 [1958]. Patterns in Comparative Religion. Lincoln: University of Nebraska Press. 
Elizarenkova, Tatyana J., 1995. Language and Style of the Vedic Rșis. Albany: State University of New York Press.

Emeneau, M. B., 1988. "The Strangling Figs in Sanskrit Literature." Sanskrit Studies of M. B. Emeneau, ed. B. A. van Nooten, Berkeley: Center for South and Southeast Asia Studies, University of California (Occasional Paper No. 13), pp. 11-27. [First publ. 1949.]

Falk, Harry, 1994. "Die Kosmogonie von ṚV X 72." Wiener Zeitschrift für die Kunde Südasiens 38, pp. 1-22.

Faulkes, Anthony (tr.), 1987. Snorri Sturluson: Edda. London: Everyman.

Feller, Danielle, 2004. The Sanskrit Epics' Representation of Vedic Myths. Delhi: Motilal Banarsidass.

Geldner, Karl F. (tr.), 1951-57. Der Rig-Veda: Aus dem Sanskrit ins Deutsche übersetzt. I-III. Cambridge, Massachusetts: Harvard University Press.

Gonda, Jan, 1963. The Vision of the Vedic Poets. The Hague: Mouton \& Co.

1975. A History of Indian Literature. Vol. 1,1: Vedic Literature. Wiesbaden: Otto Harrassowitz.

1985. "Soma, Amrta and the Moon." Change and Continuity in Indian Religion, New Delhi: Munshiram Manoharlal, pp. 3870.

Grassmann, Hermann, 1996 [1873]. Wörterbuch zum Rig-Veda. (6th expanded edn., ed. M. Kozianka. [1 ${ }^{\text {st }}$ edn. 1873.]) Wiesbaden: Harrassowitz.

Haug, Martin, 1875. "Vedische Räthselfragen und Räthselsprüche. (Uebersetzung und Erklärung von Rigv. 1, 164.)" Sitzungsberichte der philosophisch-philologischen und historischen Classe der Königl. bayerischen Akademie der Wissenschaften zu München, pp. 457-515.

Hillebrandt, Alfred, 1913. Lieder des Rgveda. Göttingen: Vandenhoeck \& Ruprecht. 
1999. Vedic Mythology. I-II. (Tr. S. R. Sarma.) Delhi: Motilal Banarsidass.

Holmberg, Uno, 1996. Der Baum des Lebens. Bern: Edition Amalia. [1 $1^{\text {st }}$ edn. 1922.]

Houben, Jan E. M., 2000. "The Ritual Pragmatics of a Vedic Hymn: The 'Riddle Hymn' and the Pravargya Ritual." Journal of the American Oriental Society Vol. 120, No. 4, pp. 499-536.

Hultkrantz, Åke, 1996. "A New Look at the World Pillar in Arctic and Sub-Arctic Religions.” In Juha Pentikäinen (ed.), Shamanism and Northern Ecology, Berlin: Walter de Gruyter, pp. 31-50.

Jackson, Peter, 2001. "A Graeco-Avestan Parallel Regarding the Adornment of the Sky with Stars." Indogermanische Forschungen 106, pp. 122-25.

Jacoby, Adolf, 1928. "Der Baum mit der Wurzel nach oben und den Zweigen nach unten." Zeitschrift für Missionskunde und Religionswissenschaft 43, pp. 78-85.

Jamison, Stephanie W., and Joel P. Brereton (tr.), 2014. The Rigveda: The Earliest Religious Poetry of India. I-III. New York: Oxford University Press.

Johansson, Karl Ferdinand, 1910. Solfågeln i Indien. En religionshistorisk-mytologisk studie. Uppsala: A.-B. Akademiska Bokhandeln.

Johnson, Willard, 1980. Poetry and Speculation in the Rg Veda. Berkeley \& Los Angeles: University of California Press.

Kagarow, Eugen, 1929. "Der umgekehrte Schamanenbaum." Archiv für Religionswissenschaft 27, pp. 183-85.

Keith, Arthur Berriedale, 2007 [1925]. The Religion and Philosophy of the Veda and Upanishads. I-II. Delhi: Motilal Banarsidass.

Kirfel, Willibald, 1967 [1920]. Die Kosmographie der Inder. Hildesheim: Georg Olms Verlagsbuchhandlung.

Klaus, Konrad, 1986. Die altindische Kosmologie. Nach den Brāhmanas dargestellt. Bonn: Indica et Tibetica Verlag. 
Knipe, David M., 1967. "The Heroic Theft: Myths from Rgveda IV and the Ancient Near East." History of Religions Vol. 6, No. 4, pp. 328-60.

Krick, Hertha, 1982. Das Ritual der Feuergründung (Agnyādheya). (Ed. G. Oberhammer.) Vienna: Verlag der Österreichischen Akademie der Wissenschaften.

Kuhn, Adalbert, 1859. Die Herabkunft des Feuers und des Göttertranks. Berlin: Ferdinand Dümmler's Verlagsbuchhandlung.

Kuiper, F. B. J., 1974. "ví dayate and vidátha-." Indologica Taurinensia 2, pp. 121-32.

1979a. "The Accent of vidátha-." Indo-Iranian Journal Vol. 21, No. 4, pp. 273-74.

1979b. Varuna and Vidūsaka: On the Origin of the Sanskrit Drama. Amsterdam: North-Holland Publishing Company. 1983. Ancient Indian Cosmogony. Ed. J. Irwin. Delhi: Vikas. 1996. "Gandharva and Soma." Studien zur Indologie und Iranistik 20, pp. 225-55.

Kunhan Raja, C., 1956. Asya vāmasya Hymn (The Riddle of the Universe). Rgveda 1-164. Sanskrit Text with the Bhassyas of Säyana and Ātmānanda and with English Translation and Notes. Madras: Ganesh \& Co.

Liebert, Gösta, 1968/1969. "Beitrag zur Frage des Polarsterns in der altindischen Literatur." Orientalia Suecana 17, pp. 155-70.

Lommel, Hermann, 1978. Kleine Schriften, ed. K. Janert, Wiesbaden: Franz Steiner Verlag.

Lüders, Heinrich, 1951. Varuna. I: Varuna und die Wasser. (Ed. L. Alsdorf.) Göttingen: Vandenhoeck \& Ruprecht.

1959. Varuna. II: Varuna und das Rta. (Ed. L. Alsdorf.) Göttingen: Vandenhoeck \& Ruprecht.

Macdonell, Arthur A., 1897. Vedic Mythology. Strassburg: Verlag von Karl J. Trübner. 
Macdonell, Arthur A., and Arthur Berriedale Keith, 2007 [1912]. Vedic Index of Names and Subjects. I-II. Delhi: Motilal Banarsidass.

Mayrhofer, Manfred, 1986. Etymologisches Wörterbuch des Altindoarischen. I-III. Heidelberg: Carl Winter Universitätsverlag.

Meletinsky, Eleazar M., 1998. The Poetics of Myth. New York \& London: Garland.

Mitchiner, John E., 2000 [1982]. Traditions of the Seven Rșis. Delhi: Motilal Banarsidass.

Müller, Rolf, 1970. Der Himmel über dem Menschen der Steinzeit. Berlin \& Heidelberg: Springer Verlag.

Oberlies, Thomas, 1998. Die Religion des Rgveda. Erster Teil: Das religiöse System des Rgveda. Vienna: Institut für Indologie der Universität Wien.

_ 2007. "Honig, Bienen und Zwillinge: Vom indogermanischen Ritual der 'Götterbewirtung' zum vedischen Argha." Studien zur Indologie und Iranistik 24, pp. 141-71.

_ 2012. Der Rigveda und seine Religion. Berlin: Verlag der Weltreligionen.

O'Flaherty, Wendy Doniger, 1981. The Rig Veda: An Anthology. Harmondsworth: Penguin.

Oldenberg, Hermann, 1894. Die Religion des Veda. Berlin: Verlag von Wilhelm Hertz. 1909-12. Rgveda. Textkritische und exegetische Noten I-II. Berlin: Weidmannsche Buchhandlung. - 1967. Kleine Schriften I. (Ed. Klaus L. Janert.) Wiesbaden: Franz Steiner Verlag.

Parpola, Asko, 2015. The Roots of Hinduism: The Early Aryans and the Indus Civilization. New York: Oxford University Press.

Paulson, Ivar, Åke Hultkrantz, and Karl Jettmar, 1962. Die Religionen Nordeurasiens und der amerikanischen Arktis. Stuttgart: W. Kohlhammer. 
Ransome, Hilda M., 2014 [1937]. The Sacred Bee in Ancient Times and Folklore. New York: Dover Publications.

Renou, Louis, 1958. Études sur le vocabulaire du Rgveda. Pondichéry: Institut français d'indologie.

1967. Études védiques et pāninéennes. Tome XVI. Paris: Éditions E. de Boccard.

Roesler, Ulrike, 1997. Licht und Leuchten im Rgveda. Untersuchungen zum Wortfeld des Leuchtens und zur Bedeutung des Lichts. Swisttal-Odendorf: Indica et Tibetica Verlag.

Rolland, Pierre, 1972. Le Mahāvrata. Contribution à l'étude d'un rituel solennel védique. Göttingen: Vandenhoeck \& Ruprecht.

Rönnow, Kasten, 1927. Trita Äptya. Eine vedische Gottheit. Uppsala: A.-B. Lundequistska Bokhandeln.

Roscher, W. H., 1883. Nektar und Ambrosia. Leipzig: B. G. Teubner.

Scherer, Anton, 1953. Gestirnnamen bei den indogermanischen Völkern. Heidelberg: Carl Winter Universitätsverlag.

Schmidt, Hanns-Peter, 1980. "The Sēnmurw: Of Birds and Dogs and Bats". Persica 9, pp. 1-85.

Schneider, Ulrich, 1971. Der Somaraub des Manu. Mythus und Ritual. Wiesbaden: Otto Harrassowitz.

Sieg, Emil, 1923. "Der Nachtweg der Sonne nach der vedischen Anschauung." Nachrichten der Gesellschaft der Wissenschaften zu Göttingen, Phil.-Hist. Kl., I, pp. 1-23.

Smith, Brian K., 1994. Classifying the Universe: The Ancient Indian Varna System and the Origin of Caste. New York: Oxford University Press.

Smith, Frederick M., 2009. Deity and Spirit Possession in South Asia. Delhi: Motilal Banarsidass.

Speyer, J. S., 1906. "A Remarkable Vedic Theory about Sunrise and Sunset." Journal of the American Oriental Society Vol. 38, No. 3, pp. 723-27. 
Staal, Frits, 2010 [1983]. Agni: The Vedic Ritual of the Fire Altar. I. Delhi: Motilal Banarsidass.

Sternberg, Leo, 1930. "Der Adlerkult bei den Völkern Sibiriens." Archiv für Religionswissenschaft 28, pp. 125-53.

Thieme, Paul, 1949. Untersuchungen zur Wortkunde und Auslegung des Rigveda. Halle: Max Niemeyer.

_ 1968. “Ambrosia.” In R. Schmitt (ed.), Indogermanische Dichtensprache, Darmstadt: Wissenschaftliche Buchgesellschaft, pp. 113-32.

Thite, G. U., 1975. Sacrifice in the Brāhmana-Texts. University of Poona.

van Buitenen, J. A. B. (tr.), 1978. The Mahābhārata: 4. The Book of Virāta. 5. The Book of the Effort. Chicago: University of Chicago Press.

Viennot. Odette, 1954. Le culte de l'arbre dans l'Inde ancienne. Paris: Presses universitaires de France.

Vodskov, H. S., 1897. Sjaeledyrkelse og naturdyrkelse I. Veda og Edda. Copenhagen: Lehmann \& Stage.

Wensinck, A. J., 1921. Tree and Bird as Cosmological Symbols in Western Asia. Amsterdam: Johannes Müller.

West, E. W., 1880. Pahlavi Texts I. Oxford: Clarendon Press.

West, Martin L., 2007. Indo-European Poetry and Myth. New York: Oxford University Press.

Wilden, Eva, 2000. Der Kreislauf der Opfergaben im Veda. Stuttgart: Franz Steiner Verlag.

Wilke, Georg, 1922. "Der Weltenbaum und die beiden kosmischen Vögel in der vorgeschichtlichen Kunst." Mannus Vol. 14, No. 1, pp. 73-99.

Witzel, Michael, 1984. "Sur le chemin du ciel." Bulletin d'Études Indiennes 2, pp. 213-79. 1996. "Looking for the Heavenly Casket." Studien zur Indologie und Iranistik 20, pp. 531-44. 
1999. "The Pleiades and the Bears viewed from inside the

Vedic Texts." Electronic Journal of Vedic Studies Vol. 5, No. 2.

Witzel, Michael, Toshifumi Gotō et al., 2013 [2007]. Rig-Veda: Das heilige Wissen. Erster und zweiter Liederkreis, Frankfurt am Main \& Leipzig: Verlag der Weltreligionen. 